\title{
The impact of institutional investors on mergers \& acquisitions in the United Kingdom
}

\author{
Dimitris Andriosopoulos ${ }^{a}$ Shuai Yang ${ }^{b, *}$
}

\begin{abstract}
In this paper we investigate the impact of institutional ownership on UK mergers and acquisitions. We employ a comprehensive sample of M\&As conducted by UK acquirers from 2000 to 2010, thus including a full cycle of peak and trough in M\&A waves. We find that institutional investors increase the likelihood of an M\&A to be a large, crossborder deal, opting for full control. Moreover, institutional ownership concentration and foreign institutional ownership increase the likelihood of cross-border M\&As. In addition, we assess the influence of institutional shareholders' investment horizon and find that while investment horizon have a negative influence in encouraging cross-border M\&As, the presence of long-term investors encourages larger M\&As. Finally, even after controlling for the 2007-08 financial crisis the market reacts negatively to the announcement of cross-border M\&As.
\end{abstract}

Keywords: institutional investors, mergers and acquisitions, cross-border, investment horizon, endogeneity, financial crisis.

JEL classifications: G30, G32, G34

a Strathclyde University Business School, Department of Accounting and Finance, 100 Cathedral street, Glasgow, G4 OLN,United Kingdom

$b,{ }^{*}$ Corresponding author: China Academy of Corporate Governance, Business School, Nankai University, Tianjin, China. Tel : +86-22-23498746. E-mail:

nkyangs@nankai.edu.cn

We thank an anonymous referee, Dylan C. Thomas, and the participants of the 3rd International Conference of the Financial Engineering and Banking Society for their helpful comments and suggestions. 


\section{Introduction}

The decision to engage in mergers and acquisitions (M\&As) can significantly affect shareholder value (Gaspar et al., 2005). A number of studies identify the significant influence that institutional investors have on firms' decision making, and particularly on the US M\&As (Stulz et al., 1990; Ambrose and Megginson, 1992; Chen et al., 2007; Ferreira et al., 2010). Moreover, the holdings of institutional investors have been steadily increasing for the last few decades resulting in large shares being held by institutional investors in the US market (Derrien et al., 2014). In this study we examine the impact of institutional investors in the UK takeover market from 2000 to 2010.

Since 1986, UK firms have the flexibility to conduct a placing, which is comparable to the commitment offering of US firms. Therefore, UK firms can signal their quality via a seasoned equity offering which increases the share ownership dispersion (Slovin et al., 2000). The control of the equity markets by institutional investors has grown rapidly since the 1990s in both the US and the UK (Aguilera et al., 2006). Currently, approximately $50 \%$ of the UK equity market is controlled by institutional investors according to the Office of National Statistics. However, managers in UK firms do not have the same freedom as their US counterparts as institutional investors are able to exert greater influence and become actively involved in monitoring firms' activities (Short and Keasey, 1999). Meanwhile, UK institutional investors exhibit a significantly lower share turnover rate compared to the US market (Black and Coffee, 1994; Aguilera et al., 2006) suggesting they play a greater role in firms' monitoring. 
The size and type of shareholders can have a significant impact on firm strategy and financial performance (Thomsen and Pedersen, 2000). Moreover, institutional investors significantly affect executive compensation (Hartzell and Starks, 2003). However, different shareholder groups may not have aligned interests in the firm's developing and investment strategies, due to increased risks and organizational complexity (Tihanyi et al., 2003). Hoskisson et al., (2002) find that different types of institutional investors have heterogeneous preferences for corporate innovation that affect corporate governance and strategy.

Since institutional investors can influence corporate decisions by making their preferences known through their stock holdings and respective trading, firms adjust their strategic investment proposals to cater to their institutional shareholders (Hartzell and Starks, 2003; Tihanyi et al., 2003). Fama and Jensen (1983) and Walsh and Seward (1990) show that external governance mechanisms play an important role in curbing managerial opportunism. Moreover, institutional investors provide effective external monitoring of firm management (Bushee, 1998; Almazan et al., 2005; Chen et al., 2007). Although monitoring can be costly, a large shareholder can bear the monitoring costs as the potential returns gained from effective monitoring can be greater (Gillan and Starks, 2000). In addition, a liquid stock market allows large investors to benefit from monitoring via informed trading, leading to more monitoring and overcoming the freerider problem (Admati et al., 1994; Maug, 1998; Johnson and Greening, 1999).

We extend the US-based evidence by assessing the impact of institutional investors, 
and that of varying institutional investor characteristics, on the decision of UK firms to engage in M\&As. We find that when institutional investors hold larger stakes in acquirer firms, there is a greater likelihood of the acquirers engaging in large M\&As, and increasing the likelihood of assuming full control of the target firm. However, when we assess the impact of the five largest institutional investors, we find there is a negative relationship with the $M \& A$ deal size. We argue that this is because the largest institutional investors will be averse to engaging in large M\&As since it requires a greater portion of the acquirer's resources to be committed on the M\&A. In addition, large M\&As can potentially distort the existing corporate governance dynamics and their existing shareholdings, and the respective influence that the largest institutional investors exert on the acquiring firm.

Investing in closely held firms can better protect investors when there are difficulties of transferring the home country's strong legal protection to the host country (Burkart and Panunzi, 2006; Weitzel and Berns, 2006; Lskavyan and Spatareanu, 2011). We investigate whether institutional ownership concentration can be complemented with investor protection in cross-border M\&As. Our results show that UK firms are typically averse to assuming full control of foreign firms. However, when UK acquirers decide to engage in cross-border M\&As, they opt for full control of the foreign target firms which are larger in size and relative to their respective industry. This suggests that when UK acquirers decide to engage in cross-border M\&As, they acquire larger firms thus attempting to establish a strong foothold in the foreign market. Consequently, cross- 
border M\&As tend to be larger in deal size as opposed to domestic M\&As.

Domestic investors can have a significant edge in stock trading (Kang and Stulz, 1997; Choe et al., 1999) and enjoy informational advantages (Dvorak, 2005) over foreign investors. However, Chen et al. (2009) find that foreign investors are more sophisticated in processing information than domestic investors, in line with Seasholes (2004) who finds that foreign investors' performance is better compared to domestic investors. Moreover, foreign institutional investors can help improve firm performance and deduct capital expenditures, which play a special role in corporate governance (Gillan and Stark, 2003; Ferreira and Matos, 2008). We assess whether investor-specific characteristics such as institutional investor horizon and country of origin (foreign vs. domestic) influence acquirers' decision to engage in M\&As. We find that the presence of foreign institutional investors entices UK firms to acquire foreign targets. In addition, a higher concentration of foreign institutional investors increases the likelihood of the acquirer assuming full control and to M\&As with larger deal values. This is consistent with Ferreira et al. (2010) who find that large and foreign institutional ownership increases the likelihood of a cross-border M\&A.

The results also show that across all three categories of institutional investors' horizon (i.e. short-term; medium-term, and long-term) there is a negative relationship with the likelihood of a cross-border M\&A. However, when acquirers engage in an M\&A, regardless of investment horizon, there is a greater likelihood of acquirers engaging in M\&As with large deal values. In addition, we find that a higher 
concentration of longer- and medium-horizon institutional investors increases the likelihood of acquirers assuming full control of the target firms. This suggests that institutional investors with medium- and long-term investment horizons are more actively involved in a firm's decision making and want to avoid a reduction in the value of their investments. After controlling for firm-specific and deal-specific characteristics, we find that the short-term market reaction to the M\&A announcement is not driven by the investment horizon of institutional investors.

M\&As are clustered due to stock market valuations (Shleifer and Vishny, 2003) and they occur in waves due to economic conditions at the firm level (Rhodes-Kropf and Viswanathan, 2004; Harford, 2005) and the industry level (Harford, 2005). Our sample period includes a full M\&A cycle, starting from the aftermath of the dot-com bubble when low credit prevailed and encouraged M\&As, to the 2007-08 financial crisis when liquidity dried and uncertainty increased, while paving the way for bargain M\&As or diversifying the inherent risk via cross-border M\&As. Our results are robust as we account for: the 2007-08 financial crisis as an exogenous shock; time effects; varying economic conditions; and potential endogeneity bias as active and large stock markets are likely to attract large and/or foreign institutional investors.

The rest of the paper is structured as follows. Section 2 discusses the literature and defines the hypotheses. Section 3 presents the data and descriptive statistics. Section 4 discusses the empirical results. The conclusions are in Section 5. 


\section{Theoretical Background and Hypotheses Development}

\subsection{Foreign institutional ownership}

It is argued that domestic investors are better informed which allows them to have a significant advantage in stock trading over foreign investors (Kang and Stulz, 1997; Choe et al., 2005). Similarly, Dvorak (2005) finds that domestic investors have informational advantages over foreign investors. In contrast, Froot and Ramadorai (2008) find a positive relationship of cross-border flow shocks to price and net asset value (NAV) returns, suggesting that foreign investors display informational advantages over domestic investors. This is in line with Seasholes (2004) who finds that foreign investors perform significantly better compared to domestic investors when trading in shares of large firms in emerging markets. Chen et al. (2009) find that when foreign and domestic investors have access to the same information, it is the foreign investors' sophistication and better information processing ability that allows them to earn better returns. Croci et al. (2012) and Fernandes et al. (2013) find that foreign institutional investors have a significant impact on CEO compensation, suggesting that foreign institutional investors can affect firm policy and decision making.

Cultural distance and asymmetric information are significant determinants of crossborder M\&As. Therefore cross-border transactions require more skilled and experienced acquirers (Slangen, 2006; Kang and Kim, 2010; Dikova and Rao Sahib, 2013). Foreign institutional ownership enjoys long-run strategic information advantages compared to 
local investors, as foreign institutional ownership is strongly and positively related to both contemporaneous and subsequent firm performance (Grinblatt and Keloharju, 2000; Dvorak, 2005). Huang and Shiu (2009) find that firms in Taiwan with high foreign institutional ownership outperform those with low foreign institutional ownership. Meanwhile, foreign institutional investors can help improve firm performance and deduct capital expenditures (Gillan and Stark, 2003; Ferreira and Matos, 2008), reduce cultural distances, transaction costs and information asymmetries, and contribute to international investments (Ferreira et al., 2010).

The overwhelming majority of target firms in our sample are private firms $(98 \%$ of the domestic and $94 \%$ of the cross-border target firms are privately held) rendering it impossible to acquire accurate data on target firms' ownership and test directly whether target firms' institutional ownership impacts M\&As. Nevertheless we test whether the presence of foreign institutional ownership on bidder firms overall can have a significant impact on the M\&A decision. We expect to find a positive relationship between higher foreign institutional ownership and the likelihood of cross-border M\&As. We state our hypothesis as follows.

Hypothesis 1: Acquiring firms with greater concentration of foreign institutional ownership have a higher probability to engage in a cross-border $M \& A$.

Institutional investors can be categorized into pressure-sensitive and pressureinsensitive groups based on the influence they exert on the firms they invest in (Brickly et al., 1988; Almazan et al., 2005; Cornett et al., 2007). Cornett et al. (2007) argue that 
pressure-insensitive investors are better suited to monitor and discipline managers and they have a positive impact on firms' cash-flows and returns. Almazan et al. (2005) find that higher levels of pressure-insensitive institutional ownership are positively related to greater control on executive compensation.

Gillan and Starks (2003) suggest that foreign institutional investors are part of the pressure-insensitive investors as they have less business relations with the firms they invest in. Hence, foreign institutional investors can potentially influence corporate governance but it is unclear whether they can act as pressure-insensitive investors with an active monitoring role. Furthermore, foreign investors provide alternative financing resources and also share the risk of domestic stock markets (Bekaert and Harvey, 2000; Gupta and Yuan, 2009; Li et al., 2011). Foreign capital can promote the economic growth by lowering the cost of external capital (Bekaert and Harvey, 2000) while improving the quality of information in local markets and thus substantially decreasing transaction costs and risk exposure ( $\mathrm{Li}$ et al., 2011). We argue that foreign institutional investors are active monitors as part of pressure-insensitive investors. Our hypothesis is stated as follows.

Hypothesis 2: Foreign institutional ownership of acquiring firms has a positive relationship with the deal size of $M \& A s$.

\subsection{Block institutional ownership}

Large institutional investors can have a greater monitoring impact, compared to small investors, in order to protect their sizable investment and enhance the value of their investment (Del Guercio and Hawkins, 1999; Gillan and Starks, 2003; Brav et al., 2008). 
However, large non-institutional investors can apply effective monitoring skills (Shleifer and Vishny, 1986; Agrawal and Gershon, 1990; Hartzell and Starks, 2003), similar to large institutional investors even though they may be facing their own agency problems (Kahl and Gorton, 1999). Gillan and Starks (2003) argue that only shareholders with large positions are likely to earn a return on their investment that is large enough to justify the monitoring costs involved. Meanwhile, large shareholders are more willing to focus on the long-term performance of the firms they invest in. Therefore, large shareholders will encourage managers to focus on long-term profitability (Dharwadkar et al., 2008). We argue that large institutional investors, captured by the holdings of the largest investor, will be effective monitors and will have a significant impact on M\&As. The testable hypothesis is stated as follows.

Hypothesis 3: The ownership stake of the largest institutional shareholder has a significant impact on the deal size of $M \& A s$.

For cross-border investments, the home country's strong legal protection may be difficult to transfer to the host country. Therefore, a high level of ownership concentration can enhance shareholder protection (Weitzel and Berns, 2006; Lskavyan and Spatareanu, 2011). Lskavyan and Spatareanu (2011) find that while weak shareholder protection in the host country reduces foreign direct investments, it is less pronounced for firms that are more closely held, suggesting a substitution effect.

Blockholders can serve as effective monitors of managerial performance or facilitate takeovers (Shleifer and Vishny, 1986). Greater concentrated institutional ownership 
induces better monitoring while other small institutional investors might have fewer incentives to engage in the costly monitoring activities (Burns et al., 2010). Clyde (1997) finds that firms with high level institutional concentration are more likely to use takeovers. We expect to find that a higher concentration of institutional investors will influence acquirers' decision to engage in M\&As. Hence, we state our testable hypothesis as follows.

Hypothesis 4: Acquiring firms with greater concentration of total institutional ownership have a higher probability to engage in a cross-border $M \& A$.

\subsection{Investment horizon of institutional shareholders}

Dong and Ozkan (2008) and Bushee (1998) find that institutional investors with long-term investment horizon are effective monitors when they are actively involved in the firm's decision making. Bushee (1998) argues that the presence of a large proportion of institutional investors with high portfolio turnover and momentum trading significantly encourages managers' myopic investment behavior.

The portfolio turnover of institutional investors in the UK is significantly lower compared to the US (Black and Coffee, 1994; Aguilera et al., 2006). This relative stability and longer-term horizon may encourage more UK institutional investors to increase their monitoring of firms and influence their respective decision making in order to enhance firm performance or reduce strategic risk, rather than simply sell shares of companies that are underperforming (Clark and Hebb, 2004; Aguilera et al., 2006). We test whether the investment horizon of institutional investors exerts greater influence on 
M\&A strategies. The testable hypothesis is stated as follows.

Hypothesis 5: The investment horizon of institutional investors has a significant impact on the deal size of $M \& A s$.

\section{Data and Descriptive Statistics}

We identify all mergers and acquisitions reported in Bureau Van Dijk from 01:2000 to $12: 2010$. We select only deals where the acquirers are UK firms. The final sample is selected by complying with the following conditions. 1) The bidder has both equity ownership records available from Thomson Reuters and financial records at the year-end prior to the announcement from Worldscope. 2) The transaction is completed at the end of the sample period. 3) All financial bidder and target firms are excluded from the sample (2-dig SIC 60-69) as in Elyasiani and Jia (2010). 4) We exclude deals with a value less than $£ 0.1$ million. 5) Targets are both UK and non-UK firms, including listed, private, and subsidiary firms. These criteria yield a final sample of 3,697 completed M\&A deals undertaken by UK public listed companies, comprising 2,242 domestic targets $(61 \%)$ and 1,455 foreign targets (39\%).

Firm-level institutional ownership characteristics are obtained from Thomson Reuters ${ }^{1}$ which compiles information contained quarterly in the $13 \mathrm{~F}$ historical holders. We calculate the proportion of foreign institutional ownership, domestic institutional

\footnotetext{
${ }^{1}$ Thomson Reuters has a minimum of $0.015 \%$ threshold for UK firms' ownership record
} 
ownership as well as total institutional ownership in each firm at the year-end prior to the deal announcement, as in Aggarwal et al. (2011) and Cornett et al. (2007). Meanwhile we examine possible effects of concentrated institutional ownership. For measuring institutional ownership concentration we follow Hartzell and Starks (2003) and Bhojraj and Sengupta (2003) and employ two alternative variables: the percentage shareholdings of the largest institutional ownership proportion; and the cumulative five largest shareholdings held by institutional investors. Finally, for the investment horizon of institutional owners we apply the three investment categories, namely low-turnover, moderate-turnover and high-turnover institutional ownership as defined in Thomson Reuters. ${ }^{2}$ All the variable descriptions are provided in Table 1.

[Insert Table 1 about here]

Table 2 presents the annual distribution of all M\&A deals announced and completed by UK listed bidder firms from 2000 to 2010 including both domestic and cross-border deals. The total value of cross-border M\&As (approximately $£ 300$ billion) is a significant proportion of the total value of M\&A deals (approx 77\%) undertaken by UK bidders

\footnotetext{
${ }^{2}$ The three main categories of institutional shareholders' investment horizon provided in Thomson Reuters are defined as follows. Low-turnover: Annual portfolio turnover rate is less than or equal to 50\%; therefore, the average holding period exceeds 2 years and is indicative of a general preference for longer term investing. Moderate-turnover: Annual portfolio turnover rate is greater than $50 \%$ and less than or equal to $100 \%$; therefore, the average holding period is between 1 year and 2 years and is indicative of a medium term investment horizon. High-turnover: Annual portfolio turnover rate is greater than 100\%; therefore, the average holding period is less than 1 year and is indicative of either a shorter term investment horizon or more frequent trading around a core position
} 
between 2000 and 2010. This shows that cross-border M\&As are mostly large deals while domestic deals are more frequent but smaller in size.

[Insert Table 2 about here]

Table 3 reports the descriptive statistics for all binary variables and industry classifications included in our tests. The figures show that firms engaging in cross-border M\&As target more listed firms in which they have larger existing shareholdings, as opposed to domestic deals. This serves as an early indication that acquirers target crossborder firms with comparatively lower information asymmetries, since, listed foreign firms in which the bidders already own a stake are bound to have lower information asymmetries. This is consistent with Cho and Padmanabhan (2005), Slangen (2006), and Kang and Kim (2010). Moreover, the results show that the mining and services industries are more prominent in cross-border M\&As and are the dominant industries for M\&As overall.

[Insert Table 3 about here]

The descriptive statistics presented in Table 4 show that the total institutional ownership of acquirer firms is on average $49.35 \%$. This is consistent with Franks and Mayer (1997) and Goergen and Renneboog (1998) who show that institutional investors are the dominant shareholding group in the UK. The average foreign institutional ownership is $10.04 \%$ which is similar to the $11.30 \%$ foreign institutional ownership reported in Ferreira et al. (2010). Domestic institutional investors control on average $39.30 \%$. The average shareholding of the five largest institutional investors is $24.27 \%$, 
while the largest institutional investor holds on average $8.93 \%$. Moreover, the figures show that institutional investors have a predominantly low-turnover ratio $(37.54 \%)$ suggesting they have a longer-term investment horizon. This is in line with Black and Coffee (1994) and Aguilera et al. (2006) who find that UK institutional investors have a significantly low turnover ratio while indicating they may play an active role in firms' decision making process.

\section{[Insert Table 4 about here]}

\section{Empirical Evidence}

\subsection{Univariate analysis}

We analyze the differences in the institutional ownership and firm-level characteristics between domestic and cross-border M\&As. The results, reported in Table 5, show that institutional shareholders hold statistically larger stakes in firms conducting cross-border M\&As (55.66\%) compared to domestic deals (45.14\%). Moreover, foreign institutional investors have greater control (13.91\%) of bidder firms targeting foreign firms, compared to targeting domestic firms (7.46\%). This suggests that the presence of foreign institutional investors may play an active role in encouraging cross-border M\&As. The results also show that compared to domestic deals, cross-border M\&As are conducted by acquiring firms in which institutional investors with low share turnover own greater stakes. In addition, UK acquirers conducting cross-border M\&As have larger institutional ownership concentration. This indicates that institutional ownership 
concentration may complement shareholder protection, hence, encouraging firms to engage in cross-border investments (Burkart and Panunzi, 2006; Weitzel and Berns, 2006; Lskavyan and Spatareanu, 2011).

The results on firm-specific characteristics show that acquirers undertaking crossborder M\&As are larger with higher leverage and share turnover rate, and deliver better shareholder returns. This suggests that cross-border M\&As involve acquirers that are more able to alleviate potential hurdles and acquire large target firms. Finally, the results show that foreign target firms are significantly larger than the average market capitalization of their industry, as the average target is more than 100 times larger than the average industry size. This indicates that foreign targets are the dominant players in each industry in terms of size suggesting that bidders acquire not just any firm but the largest participants in the industry, hence, aiming to capture a larger market share in the foreign market.

[Insert Table 5 about here]

Subsequently, we partition our sample into two groups based on whether acquirers assume partial or full control of target firms. The results presented in Table 6 show that firms in which the five largest institutional investors own larger stakes (24.84\%) and total institutional ownership is higher $(50.17 \%)$ take full control of their target firms. Moreover, we find that the domestic institutional ownership, low-turnover institutional ownership, and the ownership of the largest institutional investor are higher for firms acquiring the full control of target firms compared to partial control. In addition, 
acquirers that assume full control of the target firms have higher liquidity (captured by cash and equivalents) and profitability (proxied by ROA). In contrast, firms obtaining full control have foreign investors holding smaller stakes $(9.48 \%)$ as opposed to firms acquiring partial control $(11.68 \%)$., which is contrary to Ferreira et al. (2010). Finally, firms acquiring partial control tend to be larger and have higher share turnover rates.

$$
\text { [Insert Table } 6 \text { about here] }
$$

We also split our sample of firms between small and large deals based on the median M\&A deal value of the overall sample. The results reported in Table 7 show that acquirers with greater institutional ownership, domestic or foreign, conduct larger deals. Overall, institutional investors own $55.46 \%$ in firms conducting large M\&As as opposed to $43.10 \%$ owned in acquirers conducting smaller M\&As. Moreover, institutional investors with long investment horizon (low-turnover) own greater stakes in acquirers conducting larger M\&As. Finally, the results show that larger M\&As involve larger target firms either in terms of absolute size or industry-relative size.

[Insert Table 7 about here]

\subsection{Determinants of cross-border $M \& A s$}

In this section we perform a series of probit regressions in order to examine the role of institutional ownership characteristics on M\&As. The dependent variable takes the value of one for cross-border M\&As and zero for domestic M\&As. Since a number of bidder firms undertake multiple M\&As during our sample period, we run the regressions with cluster-adjusted robust standard errors (Petersen, 2009), therefore enabling us to 
provide robust results and interpretations (Cameron et al., 2008).

An active and large stock market may attract inherently large and/or foreign institutional investors, resulting to a potential endogeneity bias in our estimations. Therefore, we test for potential endogeneity bias $^{3}$ between the country of the target firm and the type of institutional investor in each model for every estimation method. As we find that endogeneity is present, we also report the second-step estimation outputs with the inclusion of the treated instrumental variable. We use the type of institutional investor as instrumental variable. Then, following Bris and Cabolis (2008) we regress the type of institutional investor in each relevant equation (i.e. largest institutional ownership, top 5 institutional ownership, foreign institutional ownership) against the six main categories of the International Country Risk Guide (ICRG), namely "voice and accountability", "political stability", "government effectiveness", "regulatory quality", "rule of law" and "control of corruption". La Porta et al. (1998) argue that the presence of corruption and the general country-specific factors that distort the economic and financial environment can affect foreign investment; as an extension, we argue that these factors can also affect institutional investors. Moreover, Bris and Cabolis (2008) argue that a cross-border merger affects the level of corruption that involves both the bidder and the target, and that foreign investors are affected by the corruption level in the host country.

\footnotetext{
${ }^{3}$ The individual endogeneity test results are not reported for brevity
} 
For capturing how active and competitive a market is, similar to Bris and Cabolis (2008), we use the number of total mergers and acquisitions that occur in a given target country each year. Hence, for our instrumental variable we use the aforementioned seven proxies in order to control for the potential endogeneity between the type of institutional investor and the respective country and market characteristics.

The results reported in Table 8 show that foreign institutional ownership increases the likelihood of cross-border M\&As. This is consistent with hypothesis $H 1$ that when foreign institutional investors hold greater stakes in the acquirer firm, the probability of a cross-border M\&A increases. Our findings are also in line with Ferreira et al. (2010) who argue that foreign institutional investors act as facilitators in the international market for reducing transaction costs and asymmetric information. The results show that after correcting for endogeneity, the ownership held by the five largest institutional investors has a positive and significant influence on the likelihood of a cross-border M\&A, consistent with hypothesis $H 4$. As the UK is considered to be a country with sufficient shareholder legal protection, institutional ownership concentration can help to complement the weaker legal protection of the host country (Lskavyan and Spatareanu, 2011). Similarly, we find that the level of total institutional ownership has a positive impact on the likelihood of a cross-border M\&A. However, we find no evidence that the ownership of the largest shareholder can influence the decision on whether to acquire a domestic or a cross-border target firm.

In sum, institutional ownership has a positive influence on the likelihood of a cross- 
border M\&A. This shows that institutional investors tend to be prone to cross-border M\&As and have effective monitoring skills while playing an active role in firms' decision-making and corporate strategies. When investigating the impact of institutional investors' investment-horizon, we find that across all three styles of investment turnover there is a negative and significant impact on the likelihood of a cross-border M\&A suggesting that after controlling for the type of institutional investor (e.g. foreign, or top5 institutional ownership), institutional investors influence firms' decision making. Our findings are also consistent with Bange and De Bondt (1998) and Dong and Ozkan (2006).

We do not find evidence that UK firms are more likely to bid for listed target firms. The results show that UK bidders are more likely to acquire firms that operate in the same industry. This supports the argument that asymmetric information is an important factor when considering cross-border investments (Slangen, 2006; Kang and Kim, 2010). The results on the payment method show that a cross-border M\&A is more likely to occur when it is a share payment as opposed to a cash payment, suggesting that bidder firms want to minimize the inherent risks of cross-border M\&A by utilizing their share valuations as opposed to hard cash. Finally, the results show that cross-border M\&As are more likely to involve larger target firms, in absolute terms or relative to the size of their respective industry. The results are consistent with the findings from the univariate analysis namely, that in cross-border M\&As acquirers are typically larger, wielding greater financial muscle, and that cross-border target firms are significantly larger as 
compared to domestic targets. These findings suggest that when acquirers decide to conduct a cross-border M\&A they tend to target the larger firms in their respective industry so as to obtain a strong foothold in the foreign market, hence, increasing the likelihood of an advantageous position with better returns on the investment.

$$
\text { [Insert Table } 8 \text { about here] }
$$

\subsection{Determinants of partial vs. full control of target firms}

We run a series of probit regressions for testing the factors that influence the decision to take full ${ }^{4}$ or partial control of a target firm. The dependent variable is a binary variable equal to one if the acquirer assumes full control of the target firm and zero otherwise. We also control for potential endogeneity bias due to the type of institutional investor as discussed earlier, and we employ the same instrumental variables. The results are reported in Table 9.

We find that when the target firm is a foreign firm, it is publicly traded, and operates in a different industry, it is less likely for the bidder firm to acquire full control following the M\&A. Surprisingly we find that when a bidder already holds an initial stake of the target firm it will not opt for full control. A reason for this could be due to the fact that an initial stake can lead to overbidding for the target firm, leading to a loss for the acquirer (Burkart, 1995). In addition, the results show that during the 2007-08 financial crisis

\footnotetext{
${ }^{4}$ Full control is defined as an M\&A bid that is for $100 \%$ of the target firm's shares (percentage sought) after the M\&A transaction, as in Ferreira et al. (2010).
} 
firms remained cautious and were averse in assuming full control. This is due to the uncertainty that prevailed during that period in terms of liquidity, prospective return on investments, and more importantly due to the negative shock on the supply of external financing for non-financial firms. As a consequence, corporate investment overall experienced a sharp decline following the financial crisis, especially for firms with less cash reserves and large short-term debt (Duchin et al., 2010). We also find that both cash payment and share payment have a negative impact, suggesting that bidder firms acquire full control of the target firms by using a combination of cash and shares.

\section{[Insert Table 9 about here]}

Bidder firms, in which the largest institutional investor or the five largest institutional investors hold larger stakes, are less likely to acquire full control of the target firm. An explanation for this could be that the largest institutional investors are averse to a potential dilution of their ownership and control in the new merged entity. Moreover, we find that the greater the stake held by foreign institutional investors the more likely it is for a bidder to acquire full control. We also find that the overall holdings of institutional investors, regardless of their investment horizon, are likely to influence a firm's decision to opt for full control of the target firm. Finally, we find that more acquirers that have M\&A experience are more likely to acquire full control, whereas the larger the target firm relative to the industry the less likely it is to be fully acquired. 


\subsection{Deal size determinants}

To identify whether the institutional ownership at the firm level has an impact on the deal size of M\&As we run a series of tobit regressions, as we impose a lower bound of $£ 0.1 \mathrm{~m}$ on the sample selection process. The results are reported in Table $10^{5}$ and show that in cross-border M\&As, where the target is a privately held firm operating in the same industry as the acquirer, the size of the M\&A deal is larger. Moreover, the initial stake held by a bidder firm has a negative relationship with the M\&A deal size. As expected, the deal size is negatively related to the financial crisis. This is due to two main factors. Firstly, during the financial crisis the stock valuations of both bidders and targets dropped significantly, resulting to smaller M\&As. Secondly, external financing for nonfinancial firms decreased significantly (Duchin et al., 2010), while the inability to secure external financing led a number of firms to bypass attractive investment opportunities during the crisis (Campello et al., 2008). We also find that M\&As that involve only share payments or only cash payments are larger.

Regarding the impact of institutional ownership, we find that the presence of foreign institutional investors in the bidding firm is positively related the size of the M\&A, supporting our hypothesis $(H 2)$. Moreover, the total institutional ownership has a positive and significant impact on deal size, consistent with Peng et al. (2010). This evidence

\footnotetext{
${ }^{5}$ We do not find evidence of the investor type being endogenous to the size of the M\&A deal.
} 
supports the argument that institutional ownership can help reduce external borrowing costs and therefore can help firms to get easier access to external financing and support large transactions (Faccio and Masulis, 2005; Robert and Yuan, 2010). An alternative explanation is that institutional investors prefer to invest in larger firms with lower information asymmetries and have a more stable performance, while being able to conduct large M\&As (Hessel and Norman, 1992).

The holdings of the largest institutional investor and of the top-5 institutional shareholders have a negative impact on the deal size. This is contrary to our expectations (H3) and suggests that large institutional investors are averse to large M\&As. However, after further analysis of institutional investors' investment horizon, we find that low- and moderate-turnover institutional investors have a significant and positive impact on the deal size of M\&As, supporting our hypothesis (H5). This indicates that institutional investors with medium to longer investment horizons are willing to participate in large M\&As and support investment activities with longer-term prospects. This is also in line with our previous findings that low-turnover institutional investors are more prone to cross-border M\&As which tend to involve the acquisition of larger target firms.

When controlling for past M\&A experience, the evidence shows that firms that are more likely to undertake large M\&As are those firms that are already familiar with M\&As, and therefore have expertise on how to efficiently acquire and integrate a new firm in their business model. Finally, as expected, the results show that larger target firms are involved in large M\&A deals. 
[Insert Table 10 about here]

\subsection{Investor returns surrounding $M \& A$ announcements.}

In this section we assess the shareholder returns surrounding M\&A deal announcements based on different M\&A size and the country of origin of the target firm.

Due to our sample construction and the fact that the overwhelming majority of target firms are not listed, we turn our focus on the abnormal returns generated by the bidder firms at the time of the M\&A announcements. The results are presented in Table 11. Panel A reports the cumulative abnormal returns (CARs) for different short-term holding windows before, $(-20,-2)$, during $(-1,+1),(-10,+10)$, and after $(-1,+20)$ the M\&A announcement. Moreover, the results are further tabulated based on deal size (above or below the median deal size of our sample) and on whether it is a domestic or a crossborder M\&A. The results show that it is only the domestic, as opposed to the crossborder M\&As that the market reaction differs significantly. In particular, we find that domestic deals generate on average higher abnormal returns $(0.75 \%)$ over the three days surrounding the announcement compared to cross-border deals $(0.33 \%)$.

\section{[Insert Table 11 about here]}

We further test whether the short-term returns surrounding the deal announcements are driven by deal-specific and/or investor-specific characteristics. The results, reported in Panel B of Table 11, show that the returns generated during the three days around the announcement are positively and statistically affected by the presence of foreign institutional investors and by the overall presence of institutional investors. This is 
consistent with Froot and Ramadorai (2008), Seasholes (2004) and Chen et al. (2009) who find that foreign investors have informational advantage over domestic investors. Moreover, we find that when bidders acquire target firms via a share payment method and the target firm is large relative to its peers, the market reacts positively over the three-day window surrounding the M\&A announcement. The results on the preannouncement CARs show that when the target is a listed firm, there is decline in the bidders' share price prior to the announcement.

The 2007-08 financial crisis has a negative impact on the market returns surrounding M\&A announcements. In addition, we find no evidence that the institutional investors' share turnover has any impact on the three-day window. However, the results show that low-turnover institutional ownership is positively related to the extended event window $(-10,+10)$ and the pre-event window. In contrast, high-turnover institutional investors have a negative impact to the market reaction prior to the M\&A announcement. Finally, the results show that prior M\&A experience has no impact on the market reaction during the three days surrounding the M\&A announcement, however, it has a negative impact on the extended 20-day event and pre-event windows.

\section{Summary and conclusion}

Institutional investors can be effective external monitors and can exert significant influence on firms' decision making process. This paper investigates the impact of institutional investors on M\&As conducted by UK acquirers. The results show that high 
level of total institutional ownership is positively related to cross-border M\&A deals, full control acquisitions and large M\&A deals. This suggests that institutional ownership concentration can help protect shareholders' interests and ${ }_{2}$ particularly in cross-border deals $_{2}$ lower shareholder protection may apply.

However, by using only a "crude" measurement of overall institutional ownership without accounting for differences between them, in terms of type and investment style, can lead to misconceptions. Therefore, we delve deeper into institutional investors' type, namely, domestic vs. foreign, investment horizon, and ownership concentration. We find that firms with a higher proportion of foreign institutional shareholders are more likely to conduct cross-border and large deals. This suggests that foreign institutional investors can act as facilitators for reducing transaction costs and asymmetric information in the international market. In addition, we find that a higher concentration of foreign institutional investors increases the likelihood of acquirers assuming full control and is positively related to the deal size of M\&As, in line with Ferreira et al. (2010).

Moreover, we find that the largest institutional investor is averse to engaging in large M\&As. We argue that this is because larger M\&As commit a greater portion of the acquirer's resources and can potentially distort the existing corporate governance dynamics and the influence they exert. We also find that across all three categories of institutional investors' horizon (i.e. short-term; medium-term, and long-term) there is a negative relationship with the likelihood of a cross-border M\&A. In addition, we find that a higher concentration of institutional investors with longer-, and medium-term 
horizons increases the likelihood of acquirers assuming full control of the target firms, suggesting that this type of institutional investors are more actively involved in a firm's decision making and want to avoid a reduction in the value of their investments. After controlling for firm-specific and deal-specific characteristics, we find that the short-term market reaction to the M\&A announcement is not driven by the investment horizon of the institutional investors. After controlling for firm-specific and deal-specific characteristics, there is no evidence of the market-reaction being driven by the investment horizon of institutional investors.

A limitation of this study is that it does not assess the ownership structure of target firms due to data limitation which does not allow direct testing of the impact of institutional ownership from the target firms' perspective. The inclusion of which can form the basis for further investigation and shed more light on the influence different investor types can have on corporate strategic decision making such as M\&As. Finally, our results for the equity market in the United Kingdom and respective M\&A activity corroborate the findings of Ferreira et al. (2010. 


\section{References}

Admati, A. R., Pfleiderer, P. \& Zechner, J. (1994), "Large Shareholder Activism, Risk Sharing, and Financial Market Equilibrium." Journal of Political Economy, Vol. 102, No.6: pp. 1097-1130.

Aggarwal, R., Erel, I., Ferreira, M. \& Matos, P. (2011), "Does Governance Travel Around the World? Evidence from Institutional Investors." Journal of Financial Economics, Vol. 100, No.1: pp. 154-181.

Aggrawal, A. \& Gershon, N. M. (1990), "Large Shareholders and the Monitoring of Managers: The Case of Antitakeover Charter Amendments." The Journal of Financial and Quantitative Analysis, Vol. 25, No.2: pp. 143-161.

Aguilera, R. V. \& Williams, C. A., Conley, J. M. \& Rupp, D. E. (2006), "Corporate Governance and Social Responsibility: a comparative analysis of the UK and the US*." Corporate Governance: An International Review, Vol. 14, No.3: pp. 147-158.

Almazan, A., Hartzell, J. C. \& Starks, L. T. (2005), "Active Institutional Shareholders and Costs of Monitoring: Evidence from Executive Compensation." Financial Management, Vol. 34, No.4: pp. 5-34

Ambrose, B.W., Megginson, W.L. (1992), "The Role of Asset Strucutre, Ownership Strucutre, and Takeover Defenses in Determining Acquisition Likelihood. " Journal of Financial and Quantitative Analysis, Vol. 27, No. 4: pp. 575-589.

Bange, M. M. \& De Bondt, W. F. M. (1998), "R\&D budgets and corporate earnings targets." Journal of Corporate Finance, Vol. 4, No.2: pp. 153-184.

Bekaert, G. \& Harvey, C. R. (2000). "Foreign Speculators and Emerging Equity Markets." Journal of Finance, Vol. 55, No.2: pp. 565-613.

Bhojraj, S. \& Sengupta, P (2003), "Effect of Corporate Governance on Bond Ratings and Yields: The Role of Institutional Investors and Outside Directors." The Journal of Business, Vol. 76, No.3: pp. 455-475.

Black, B. S. \& Coffee, J. C., Jr. (1994), "Hail Britannia?: Institutional Investor Behavior under Limited Regulation." Michigan Law Review, Vol. 92, No.7: pp. 1997-2087.

Brav, A. \& Jiang, W. E. I., Partnoy, F. \& Thomas, R. (2008), "Hedge Fund Activism, Corporate Governance, and Firm Performance." Journal of Finance, Vol. 63, No.4: pp. 1729-1775.

Brickley, J. A., Lease, R. C. \& Smith Jr, C. W. (1988), "Ownership Structure and Voting on Antitakeover Amendments." Journal of Financial Economics, Vol. 20, No.1-2: pp. 267291.

Bris A., Cabolis, C. (2008), "The Value Investors Protection: Firm Evidence from Cross- 
Border Mergers." Review of Financial Studies, Vol. 21, No.2: pp.605-648.

Burkart, M. (1995), "Initial Shareholdings and Overbidding in Takeover Contests." Journal of Finance, Vol. 50, No.5: pp. 1491-1515.

Burns, N., Kedia, S. \& Lipson, M. (2010), "Institutional Ownership and Monitoring: Evidence from Financial Misreporting." Journal of Corporate Finance, Vol. 16, No.4: pp. 443-455.

Burkart, M. \& Panunzi, F. (2006), "Agency Conflicts, Ownership Concentration, and Legal Shareholder Protection." Journal of Financial Intermediation, Vol. 15, No.1: pp. 1-31.

Bushee, B. J. (1998), "The Influence of Institutional Investors on Myopic R\&D Investment Behavior." The Accounting Review, Vol. 73, No.3: pp. 305-333.

Cameron, A. C., Gelbach, J. B. \& Miller, D. L. (2008), "Bootstrap-Based Improvements for Inference with Clustered Errors." Review of Economics and Statistics, Vol. 90, No.3: pp. 414-427.

Campello, M., Graham, J. R. \& Harvey, C. R. (2010), "The Real Effects of Financial Constraints: Evidence from a Financial Crisis." Journal of Financial Economics, Vol. 97, No.3: pp. 470-487.

Chatterjee, S. \& Lubatkin, M. (1990), "Corporate Mergers, Stockholder Diversification, and Changes in Systematic Risk." Strategic Management Journal, Vol 11, No.4: pp. 255-268.

Chen, L-W., Johnson, S.A., Lin, J-C., Liu, Y-J. (2009), "Information, Sophistication, and Foreign versus Domestic Investors' Performance." Journal of Banking and Finance, Vol. 33, No. 9: pp. 1636-1651.

Chen, X., Harford, J. \& Li, K. (2007), "Monitoring: Which Institutions Matter?" Journal of Financial Economics, Vol. 86, No.2: pp. 279-305.

Cho, K. R. \& Padmanabhan, P. (2005), "Revisiting the Role of Cultural Distance in MNC's Foreign Ownership Mode Choice: the Moderating Effect of Experience Attributes." International Business Review, Vol. 14, No.3: pp. 307-324.

Choe, H., Kho, B.-C., Stulz, R.M. (2005). "Do Domestic Investors Have an Edge? The Trading Experience of Foreign Investors in Korea. " Review of Financial Studies, Vol. 18, No.3: pp. 795-829.

Choe, H., Kho, B-C., Stulz, R.M. (1999), "Do Foreign Investors Destabilize Stock Markets? The Korean Experience in 1997. " Journal of Financial Economics, Vol. 54, No.2: pp. $227-64$

Clark, G. L. \& Hebb, T. (2004), "Pension Fund Corporate Engagement: The Fifth Stage of Capitalism." Industrial Relations, Vol. 59, No.1: pp. 142-171. 
Clyde, P. (1997), "Do Institutional Shareholders Police Management?" Managerial and Decision Economics, Vol. 18, No.1: pp. 1-10.

Cornett, M. M., Marcus, A. J., Saunders, A. \& Tehranian, H. (2007), "The Impact of Institutional Ownership on Corporate Operating Performance." Journal of Banking \& Finance, Vol. 31, No.6: pp. 1771-1794.

Croci, E., Gonec, H., Ozkan, N. (2012), "CEO Compensation, Family Control, and Institutional Investors in Continental Europe.” Journal of Banking and Finance" Vol. 36, No. 12: pp. 3318-3335.

Del Guercio, D. \& Hawkins, J. (1999), "The Motivation and Impact of Pension Fund Activism." Journal of Financial Economics, Vol. 52, No.3: pp. 293-340.

Derrien, F., Kecskés, A., Thesmar, D. (2014). "Investor Horizons and Corporate Policies." Journal of Financial and Quantitative Analysis, forthcoming.

Dharwadkar, R., Goranova, M., Brandes, P. \& Khan, R. (2008), "Institutional Ownership and Monitoring Effectiveness: It's Not Just How Much but What Else You Own." Organization Science, Vol. 19, No.3: pp. 419-440.

Dikova, D. \& Rao Sahib, P. (2013), "Is Cultural Distance a Bane or a Boon for Cross-border Acquisition Performance?" Journal of World Business, Vol. 48, No.1: pp. 77-86.

Dong, M. \& Ozkan, A. (2008), "Institutional Investors and Director Pay: An Empirical Study of UK Companies." Journal of Multinational Financial Management, Vol. 18, No.1: pp. 16-29.

Duchin, R., Ozbas, O. \& Sensoy, B. A. (2010), "Costly External Finance, Corporate Investment, and the Subprime Mortgage Credit Crisis." Journal of Financial Economics, Vol.97, No.3: pp.418-435.

Dvorak, T. (2005), "Do Domestic Investors Have an Information Advantage? Evidence from Indonesia." Journal of Finance, Vol. 60, No.2: pp. 817-839.

Elyasiani, E. \& Jia, J. (2010), "Distribution of Institutional Ownership and Corporate Firm Performance." Journal of Banking \& Finance, Vol. 34, No.3: pp. 606.

Faccio, M. \& Masulis, R. W. (2005), "The Choice of Payment Method in European Mergers and Acquisitions." Journal of Finance, Vol. 60, No.3: pp. 1345-1388.

Fama, E. F. \& Jensen, M. C. (1983), "Separation of Ownership and Control." Journal of Law and Economics, Vol. 26, No.2: pp. 301-325.

Fernandes, N., Ferreira, M. A., Matos, P. \& Murphy, K. J. (2013), "Are U.S. CEOs Paid More? New International Evidence." Review of Financial Studies, Vol. 26, No. 2:pp.323367. 
Ferreira, M. A. \& Matos, P. (2008), "The Colors of Investors' Money: The Role of Institutional Investors around the World." Journal of Financial Economics, Vol. 88, No.3: pp. 499-533.

Ferreira, M. A., Massa, M. \& Matos, P. (2010), "Shareholders at the Gate? Institutional Investors and Cross-Border Mergers and Acquisitions." Review of Financial Studies, Vol. 23, No.2: pp. 601-644.

Franks, J. \& Mayer, C. (1997), "Corporate Ownership and Control in the U.K., Germany, and France." Journal of Applied Corporate Finance, Vol. 9, No.4: pp. 30-45.

Froot K.A., Ramadorai, T. (2008), "Institutional Portfolio Flows and International Investments." Review of Financial Studies, Vol. 21, No.2: pp. 937-971

Gaspar, J., Massa, M., Matos, P. (2005). "Shareholder Investment Horizons and the Market for Corporate Control. " Journal of Financial Economics, Vol. 76, No. 1: pp. 135-165.

Gillan, S. L. \& Starks, L. T. (2000), "Corporate Governance Proposals and Shareholder Activism: the Role of Institutional Investors." Journal of Financial Economics, Vol. 57, No.2: pp. 275-305.

Gillan, S. L. \& Starks, L. T. (2003), "Corporate Governance, Corporate Ownership, and the Role of Institutional Investors: A Global Perspective." Journal of Applied Finance, Vol. 13, No.2: pp. 4-22.

Goergen, M. \& Renneboog, L. (1998), "Strong Managers and Passive Institutional Investors in the UK" SSRN working paper, No.137068.

Grinblatt, M. \& Keloharju, M. (2000), "The Investment Behavior and Performance of Various Investor Types: a Study of Finland's Unique Data Set." Journal of Financial Economics, Vol. 55, No.1: pp. 43-67.

Gupta, N. \& Yuan, K. (2009), "On the Growth Effect of Stock Market Liberalizations." Review of Financial Studies, Vol. 22, No.11: pp. 4715-4752.

Harford, J. (2005), "What Drives Merger Waves? " Journal of Financial Economics, Vol. 77, No.3: pp. 529-650.

Hartzell, J. C. \& Starks, L. T. (2003), "Institutional Investors and Executive Compensation." Journal of Finance, Vol. 58, No.6: pp. 2351-2374.

Hessel, C. A. \& Norman, M. (1992), "Financial Characteristics of Neglected and Institutionally Held Stocks." Journal of Accounting, Auditing \& Finance, Vol. 7, No.3: pp. 313-330.

Hoskisson, R. E., Hitt, M. A., Johnson, R. A. \& Grossman, W. (2002), "Conflicting Voices: The Effects of Institutional Ownership Heterogeneity and Internal Governance on Corporate Innovation Dtrategies " The Academy of Management Journal, Vol. 45, No.4: 
pp. 697-716

Huang, R. D. \& Shiu, C.-Y. (2009), "Local Effects of Foreign Ownership in an Emerging Financial Market: Evidence from Qualified Foreign Institutional Investors in Taiwan." Financial Management, Vol. 38, No.3: pp. 567-602.

Johnson, R. A. \& Greening, D. W. (1999), "The Effects of Corporate Governance and Institutional Ownership Types on Corporate Social Performance." The Academy of Management Journal, Vol. 42, No.5: pp. 564-576.

Kahl, M. \& Gorton, G. B. (1999), "Blockholder Identity, Equity Ownership Structures, and Hostile Takeovers." NBER Working Paper, No.w7123

Kang, J.-K. \& Kim, J.-M. (2010), "Do Foreign Investors Exhibit a Corporate Governance Disadvantage? An Information Asymmetry Perspective." Journal of International Business Studies, Vol. 41, No.8: pp. 1415-1438.

Kang, J-K., Stulz, R.M. (1997), "Why is there a Home Bias? An Analysis of Foreign Portfolio Equity Ownership in Japan." Journal of Financial Economics, Vol. 46, pp. 2-18.

La Porta, R., Lopez-de-Silanes, F., Shleifer, A., Vishny, R. (1998), "Law and Finance." Journal of Political Economy, Vol. 106, pp. 1113-1147.

Li, D., Nguyen, Q. N., Pham, P. K. \& Wei, S. X. (2011), "Large Foreign Ownership and Firm-Level Stock Return Volatility in Emerging Markets." Journal of Financial and Quantitative Analysis, Vol. 46, No.4: pp. 1127-1155.

Lskavyan, V. \& Spatareanu, M. (2011), "Shareholder Protection, Ownership Concentration and FDI." Journal of Economics and Business, Vol. 63, No.1: pp. 69-85.

Maug, E. (1998), "Large Shareholders as Monitors: Is There a Trade-Off between Liquidity and Control?" The Journal of Finance, Vol. 53, No.1: pp. 65-98.

Peng, F., Kang, L. \& Jiang, J. (2010), "Acquisition Size and Institutional Ownership: Evidence from China. The Chinese Economic Association (UK) 2010 Annual" Conference and 2nd CEA (Europe) Annual Conference. University of Oxford.

Petersen, M. A. (2009), "Estimating Standard Errors in Finance Panel Data Sets: Comparing Approaches." Review of Financial Studies, Vol. 22, No.1: pp. 435-480.

Rhodes-Kropf, M. \& Viswanathan, S. (2004), "Market valuation and merger waves". Journal of Finance, Vol. 59, No.6: pp. 2685-2718.

Roberts, G. \& Yuan, L. (2010), "Does Institutional Ownership Affect the Cost of Bank Borrowing?" Journal of Economics and Business, Vol. 62, No.6: pp. 604-626.

Seasholes, M.S. (2004),"Re-examining Information Asymmetries in Emerging Stock Markets." Unpublisheed Working Paper, University of California, Berkeley, CA. 
Shleifer, A. \& Vishny, R. (2003). "Stock Market Driven Acquisitions." Journal of Financial Economics, Vol. 70, No.3: pp. 295-311.

Shleifer, A. \& Vishny, R. W. (1986), "Large Shareholders and Corporate Control." Journal of Political Economy, Vol. 94, No.3: pp. 461-488.

Short, H. \& Keasey, K. (1999), "Managerial ownership and the performance of firms: Evidence from the UK." Journal of Corporate Finance, Vol. 5, No.1: pp. 79-101.

Slangen, A. H. L. (2006), "National Cultural Distance and Initial Foreign Acquisition Performance: The Moderating Effect of Integration." Journal of World Business, Vol. 41, No.2: pp. 161-170.

Stulz, R.M., Walkling, R.A., Song M.H. (1990), "The distribution of target ownership and the division of gains in successful tender offers." Journal of Finance, Vol. 45, No.3: pp. $817-833$.

Thomsen, S. \& Pedersen, T. (2000), "Ownership Structure and Economic Performance in the Largest European Companies." Strategic Management Journal, Vol. 21, No.6: pp. 689705 .

Tihanyi, L., Johnson, R. A., Hoskisson, R. E. \& Hitt, M. A. (2003), "Institutional Ownership Differences and International Diversification: The Effects of Boards of Directors and Technological Opportunity." The Academy of Management Journal, Vol. 46, No.2: pp. 195-211.

Walsh, J. P. \& Seward, J. K. (1990), "On the Efficiency of Internal and External Corporate Control Mechanisms." The Academy of Management Review, Vol. 15, No.3: pp. 421-458.

Weitzel, U. \& Berns, S. (2006), "Cross-border Takeovers, Corruption, and Related Aspects of Governance." International Business Studies, Vol. 37, No.6: pp. 786-806. 
Table 1: Description of variables

Variables

Description
Largest Institutional Investor

Top 5 Institutional Ownership

Domestic Institutional Ownership

Foreign Institutional Ownership

Total Institutional Ownership

Low-turnover Institutional Ownership

Moderate-turnover Institutional

Ownership

High-turnover Institutional Ownership

Firm Size

ROA

Leverage

Cash \& Equivalent

\section{Panel A: Firm-level Institutional Ownership variables}

Percentage shareholdings held by the largest institutional investor in the acquirer firm at the year-end prior announcement (Thomson Reuters).

Cumulative percentage shareholdings held by the top five institutional investors in the acquirer firm at the year-end prior to the deal announcement (Thomson Reuters).

Cumulative percentage shareholdings held by UK institutional investors in the acquirer firm at the year-end prior to the deal announcement (Thomson Reuters).

Cumulative percentage shareholdings held by non-UK institutional investors in the acquirer firm at the year-end prior to the deal announcement (Thomson Reuters).

Cumulative percentage shareholdings held by all institutional investors in the acquirer firm at the year-end prior deal announcement (Thomson Reuters).

Binary variable equal to one for shareholdings held by institutional investors with annual portfolio turnover rate less than or equal to $50 \%$ at the year-end prior deal announcement and zero otherwise (Thomson Reuters).

Binary variable equal to one for shareholdings held by institutional investors with annual portfolio turnover rate greater than $50 \%$ and less than or equal to $100 \%$ at the year-end prior the deal announcement and zero otherwise (Thomson Reuters).

Binary variable equal to one for shareholdings held by institutional investors with annual portfolio turnover rate greater than $100 \%$ at the year-end prior the deal announcement and zero otherwise (Thomson Reuters).

\section{Panel B Firm-specific control variables}

Natural logarithm of total assets of acquirer firm at the year-end prior to the M\&A announcement (Worldscope).

Return on assets of acquirer firm at the year-end prior to the M\&A announcement (Worldscope).

Ratio of total debt to total assets at the year-end prior to the M\&A announcement (Worldscope).

Ratio of cash and equivalents to total assets at the year-end prior to the M\&A announcement (Worldscope). 
Capital Expenditure

Intangible assets

Dividend Yield

Share Turnover

Tobin's q

Target Firm Size

Target Firm Industry-Relative Size

High-tech

Cross Industry

Listed Target

Initial Stake

Cash Payment

Share Payment

Financial Crisis

M\&A experience
Ratio of capital expenditures to total assets at the year-end prior to the M\&A announcement (Worldscope).

Ratio of total intangible assets to total assets at the year-end prior to the M\&A announcement (Worldscope).

Ratio of common cash dividends relative to the share price at the year-end prior to the M\&A announcement (Worldscope).

Number of shares traded divided by number of shares outstanding at the year-end prior to the M\&A announcement (Worldscope).

Market value of equity plus total debt and divided by book value of assets at the year-end prior to the M\&A announcement (Worldscope).

Natural logarithm of the target firms' total assets at the year-end prior to the M\&A announcement (Bureau van Dijk).

Ratio of the target firms' market capitalization to the average relative industry capitalization at the year-end prior to the M\&A announcement (Bureau van Dijk, Worldscope).

\section{Panel C: M\&A deal-related variables}

Binary variable equal to one when the target firm belongs to the high-technology industry and zero otherwise (Bureau van Dijk).

Binary variable equal to one when acquirer and target firms have different 2-digit SIC codes and zero otherwise (Bureau van Dijk).

Binary variable equal to one when the target firm is a publicly listed firm and zero otherwise (Bureau van Dijk).

Binary variable equal to one if the acquirer firm has an initial stake in target firm prior to the M\&A announcement and zero otherwise (Bureau van Dijk)

Binary variable equal to one if the M\&A deal employs cash only as payment method and zero otherwise (Bureau van Dijk).

Binary variable equal to one if the M\&A deal employs shares only as payment method and zero otherwise (Bureau van Dijk).

Binary variable equal to one if the M\&A deal is announced during the 2007-2008 crisis period and zero otherwise (Bureau van Dijk).

Binary variable equal to one if the acquirer firm has M\&A experience before the M\&A announcement and zero otherwise (Bureau van Dijk). 
Table 2: Annual distribution of UK mergers and acquisitions.

\begin{tabular}{|c|c|c|c|c|c|c|}
\hline \multirow[b]{2}{*}{ Year } & \multicolumn{2}{|c|}{ Domestic } & \multicolumn{2}{|c|}{ Cross-Border } & \multicolumn{2}{|c|}{ Total } \\
\hline & Number of Deals & Deal Value & Number of Deals & Deal Value & Number of Deals & Deal Value \\
\hline 2000 & 191 & $8,982.31$ & 155 & $162,531.40$ & 346 & $171,513.70$ \\
\hline 2001 & 176 & $4,307.13$ & 126 & $13,691.79$ & 302 & $17,998.92$ \\
\hline 2002 & 183 & $11,629.06$ & 122 & $16,105.57$ & 305 & $27,734.63$ \\
\hline 2003 & 167 & $8,486.50$ & 111 & $13,646.03$ & 278 & $22,132.52$ \\
\hline 2004 & 207 & $11,642.67$ & 138 & $7,188.77$ & 345 & $18,831.44$ \\
\hline 2005 & 258 & $8,470.20$ & 146 & $15,968.37$ & 404 & $24,438.57$ \\
\hline 2006 & 277 & $9,214.43$ & 162 & $16,080.93$ & 439 & $25,295.36$ \\
\hline 2007 & 293 & $12,847.19$ & 178 & $28,876.55$ & 471 & $41,723.74$ \\
\hline 2008 & 194 & $4,005.41$ & 137 & $15,564.03$ & 331 & $19,569.44$ \\
\hline 2009 & 130 & $2,302.03$ & 85 & $10,038.71$ & 215 & $12,340.73$ \\
\hline 2010 & 166 & $3,106.26$ & 95 & $4,710.12$ & 261 & $7,816.37$ \\
\hline Total & 2,242 & $84,993.19$ & 1,455 & $304,402.30$ & 3,697 & $389,395.50$ \\
\hline
\end{tabular}

The table presents the annual distribution of the number of M\&A deals and M\&A deal value (millions of GBP) for completed domestic and cross-border M\&As announced by UK listed bidders spanning January 1, 2000 and December 31, 2010. 
Table 3: Mean values for binary explanatory variables and major industry category.

\begin{tabular}{|c|c|c|c|c|c|c|}
\hline & \multicolumn{2}{|c|}{ Domestic } & \multicolumn{2}{|c|}{ Cross-border } & \multicolumn{2}{|c|}{ Total } \\
\hline & $\mathbf{N}$ & Mean & $\mathbf{N}$ & Mean & $\mathbf{N}$ & Mean \\
\hline \multicolumn{7}{|l|}{ Binary Variables: } \\
\hline Cross Industry & 2,242 & 0.60 & 1,455 & 0.60 & 3,697 & 0.60 \\
\hline Listed Target & 2,242 & 0.02 & 1,455 & 0.06 & 3,697 & 0.03 \\
\hline Initial Stake & 2,206 & 0.07 & 1,411 & 0.11 & 3,617 & 0.08 \\
\hline Cash Payment & 2,040 & 0.72 & 1,255 & 0.79 & 3,295 & 0.75 \\
\hline Share Payment & 2,242 & 0.19 & 1,455 & 0.11 & 3,697 & 0.16 \\
\hline Financial Crisis & 2,242 & 0.22 & 1,455 & 0.22 & 3,697 & 0.22 \\
\hline M\&A experience & 2,242 & 0.78 & 1,455 & 0.81 & 3,697 & 0.79 \\
\hline \multicolumn{7}{|l|}{ Industry Categories: } \\
\hline High-tech & 2,242 & 0.16 & 1,455 & 0.14 & 3,697 & 0.16 \\
\hline Mining & 2,242 & 0.03 & 1,455 & 0.13 & 3,697 & 0.07 \\
\hline Construction & 2,242 & 0.05 & 1,455 & 0.02 & 3,697 & 0.04 \\
\hline Manufacturing & 2,242 & 0.19 & 1,455 & 0.30 & 3,697 & 0.23 \\
\hline Transportation & 2,242 & 0.03 & 1,455 & 0.03 & 3,697 & 0.03 \\
\hline Communications & 2,242 & 0.04 & 1,455 & 0.04 & 3,697 & 0.04 \\
\hline Public Utilities & 2,242 & 0.02 & 1,455 & 0.02 & 3,697 & 0.02 \\
\hline Whole Sale Trading & 2,242 & 0.05 & 1,455 & 0.05 & 3,697 & 0.05 \\
\hline Retail Trading & 2,242 & 0.07 & 1,455 & 0.03 & 3,697 & 0.06 \\
\hline Services & 2,242 & 0.48 & 1,455 & 0.37 & 3,697 & 0.44 \\
\hline Pubic Administration & 2,242 & 0.01 & 1,455 & 0.00 & 3,697 & 0.01 \\
\hline
\end{tabular}

This table presents the mean value of binary explanatory variables based on domestic and cross-border M\&As. The total sample comprises 3,679 M\&As deals undertaken by UK public bidders from January 1, 2000 to December 31, 2010. The industry classifications are based on the 2-digit SIC codes. All variables are defined in Table 1. 
Table 4: Descriptive Statistics

\begin{tabular}{|c|c|c|c|c|c|c|}
\hline Panel A. Institutional Ownership Variables & $\mathbf{N}$ & Mean & Median & Min & Max & St. Deviation \\
\hline Largest Institutional Investor & 3,355 & 8.93 & 7.82 & 0.00 & 69.91 & 6.10 \\
\hline Top 5 Institutional Ownership & 3,355 & 24.27 & 24.18 & 0.00 & 84.30 & 13.63 \\
\hline Domestic Institutional Ownership & 3,355 & 39.30 & 40.21 & 0.00 & 98.52 & 24.45 \\
\hline Foreign Institutional Ownership & 3,355 & 10.04 & 5.13 & 0.00 & 86.34 & 13.11 \\
\hline Total Institutional Ownership & 3,355 & 49.35 & 53.21 & 0.00 & 99.91 & 28.76 \\
\hline Low-turnover institutional ownership & 3,355 & 37.54 & 38.92 & 0.00 & 91.68 & 23.72 \\
\hline Moderate-turnover institutional ownership & 3,355 & 6.87 & 5.72 & 0.00 & 48.08 & 6.36 \\
\hline High-turnover institutional ownership & 3,355 & 1.16 & 0.38 & 0.00 & 34.87 & 2.30 \\
\hline \multicolumn{7}{|l|}{ Panel B. Firm-level Characteristics } \\
\hline Deal Value (millions of GBP) & 3,697 & 105.33 & 6.22 & 0.10 & $129,240.10$ & $2,152.65$ \\
\hline Firm Size & 3,404 & 5.29 & 5.23 & 1.70 & 8.23 & 1.09 \\
\hline ROA & 3,402 & 0.00 & 0.05 & -4.17 & 0.81 & 0.26 \\
\hline Leverage & 3,382 & 0.18 & 0.15 & 0.00 & 0.99 & 0.16 \\
\hline Long-term Leverage & 3,387 & 0.13 & 0.09 & 0.00 & 0.99 & 0.15 \\
\hline Cash \& Equivalent & 3,404 & 0.15 & 0.10 & 0.00 & 1.00 & 0.18 \\
\hline Capital Expenditures & 3,338 & 0.04 & 0.03 & 0.00 & 0.94 & 0.06 \\
\hline Intangible assets & 3,401 & 0.26 & 0.21 & 0.00 & 0.97 & 0.23 \\
\hline Dividend Yield & 3,310 & 2.22 & 1.86 & 0.00 & 13.76 & 2.20 \\
\hline Share Turnover & 3,178 & 0.87 & 0.71 & 0.00 & 6.67 & 0.73 \\
\hline Tobin's q & 3,281 & 1.76 & 1.22 & 0.01 & 18.39 & 1.95 \\
\hline Target Firm Size & 1,740 & 3.47 & 3.35 & 8.01 & 1.03 & 0.00 \\
\hline Target Firm Industry-Relative Size & 768 & 111.64 & 97.59 & 0.00 & 507.32 & 89.37 \\
\hline
\end{tabular}

This table presents the descriptive statistics for the continuous variables employed in the study. Deal Value is the M\&As deal value in millions of GBP.

All variables are defined in Table 1. All accounting data are taken at year-end prior to the M\&A announcement. 
Table 5: Univariate analysis on domestic vs. cross-border M\&As

\begin{tabular}{|c|c|c|c|c|c|c|c|c|}
\hline \multirow[b]{2}{*}{ Variables } & \multicolumn{3}{|c|}{ Domestic } & \multicolumn{3}{|c|}{ Cross-Border } & \multirow{2}{*}{$\begin{array}{c}\text { Test of } \\
\text { difference } \\
\text { in means }\end{array}$} & \multirow{2}{*}{$\begin{array}{c}\text { Test of } \\
\text { difference } \\
\text { in medians }\end{array}$} \\
\hline & $\mathbf{N}$ & Mean & Median & $\mathbf{N}$ & Mean & Median & & \\
\hline Deal Value (millions of GBP) & 2,242 & 37.91 & 4.56 & 1,455 & 209.21 & 11.47 & $(0.057)^{*}$ & $(0.000)^{* * * *}$ \\
\hline Largest Institutional Investor & 2,012 & 8.91 & 7.90 & 1,343 & 8.95 & 7.72 & $(0.854)$ & $(0.959)$ \\
\hline Top 5 Institutional Ownership & 2,012 & 23.71 & 23.80 & 1,343 & 25.12 & 24.56 & $(0.003)^{* * *}$ & $(0.023)^{* *}$ \\
\hline Domestic Institutional Ownership & 2,012 & 37.68 & 38.25 & 1,343 & 41.74 & 42.93 & $(0.000)^{* * *}$ & $(0.000)^{* * *}$ \\
\hline Foreign Institutional Ownership & 2,012 & 7.46 & 2.88 & 1,343 & 13.91 & 9.54 & $(0.000)^{* * *}$ & $(0.000)^{* * *}$ \\
\hline Total Institutional Ownership & 2,012 & 45.14 & 46.79 & 1,343 & 55.66 & 60.69 & $(0.000)^{* * *}$ & $(0.000)^{* * *}$ \\
\hline Low-turnover Institutional Ownership & 2,012 & 34.64 & 34.74 & 1,343 & 41.88 & 43.75 & $(0.000)^{* * *}$ & $(0.000)^{* * *}$ \\
\hline Moderate-turnover Institutional Ownership & 2,012 & 6.39 & 5.27 & 1,343 & 7.58 & 6.35 & $(0.000)^{* * *}$ & $(0.000)^{* * *}$ \\
\hline High-turnover Institutional Ownership & 2,012 & 0.96 & 0.20 & 1,343 & 1.47 & 0.65 & $(0.000)^{* * *}$ & $(0.000)^{* * *}$ \\
\hline Firm Size & 2,033 & 5.01 & 4.99 & 1,371 & 5.70 & 5.71 & $(0.000)^{* * *}$ & $(0.000)^{* * *}$ \\
\hline ROA & 2,032 & -0.01 & 0.04 & 1,370 & 0.03 & 0.05 & $(0.000)^{* * *}$ & $(0.000)^{* * *}$ \\
\hline Leverage & 2,018 & 0.17 & 0.13 & 1,364 & 0.19 & 0.16 & $(0.033)^{* *}$ & $(0.001)^{* * *}$ \\
\hline Long-term Leverage & 2,021 & 0.12 & 0.07 & 1,366 & 0.14 & 0.10 & $(0.000)^{* * *}$ & $(0.000)^{* * *}$ \\
\hline Cash \& Equivalent & 2,033 & 0.16 & 0.09 & 1,371 & 0.15 & 0.10 & $(0.483)$ & $(0.013)^{* *}$ \\
\hline Capital Expenditures & 1,996 & 0.04 & 0.03 & 1,342 & 0.05 & 0.03 & $(0.011)^{* *}$ & $(0.000)^{* * *}$ \\
\hline Intangible Assets & 2,030 & 0.26 & 0.19 & 1,371 & 0.26 & 0.22 & $(0.749)$ & $(0.370)$ \\
\hline Dividend Yield & 1,956 & 2.13 & 1.73 & 1,354 & 2.35 & 2.08 & $(0.003)^{* * *}$ & $(0.000)^{* * *}$ \\
\hline Share Turnover & 1,868 & 0.75 & 0.58 & 1,310 & 1.05 & 0.91 & $(0.000)^{* * * *}$ & $(0.000)^{* * *}$ \\
\hline Tobin's q & 1,935 & 1.74 & 1.20 & 1,346 & 1.78 & 1.31 & $(0.509)$ & $(0.000)^{* * *}$ \\
\hline Target Firm Size & 1,297 & 3.21 & 3.21 & 443 & 4.21 & 4.04 & $(0.000)^{* * *}$ & $(0.000)^{* * *}$ \\
\hline Target Firm Industry-Relative Size & 72 & 0.56 & 0.41 & 696 & 123.13 & 107.87 & $(0.000)^{* * *}$ & $(0.000)^{* * *}$ \\
\hline
\end{tabular}

This table presents descriptive statistics of the continuous variables employed in this study for the two sub-groups of target firms: domestic (UK) and cross-border (non-UK). The variables are defined as in Table 1. All accounting data are taken at year-end prior to the M\&A deal announcement. Test of difference in means (medians) reports the p-values for the homogeneity test for means (medians) assuming unequal variances across the two target groups: domestic and cross-border targets. $* * *, * *$, and $*$ represent significance at $1 \%, 5 \%$, and $10 \%$, respectively. 
Table 6: Univariate analysis on gaining partial vs. full control following the M\&A.

\begin{tabular}{|c|c|c|c|c|c|c|c|c|}
\hline \multirow[b]{2}{*}{ Variables } & \multicolumn{3}{|c|}{ Partial Control } & \multicolumn{3}{|c|}{ Full Control } & \multirow{2}{*}{$\begin{array}{c}\text { Test of } \\
\text { difference in } \\
\text { means }\end{array}$} & \multirow{2}{*}{$\begin{array}{c}\text { Test of } \\
\text { difference } \\
\text { in medians }\end{array}$} \\
\hline & $\mathbf{N}$ & Mean & Median & $\mathbf{N}$ & Mean & Median & & \\
\hline Deal Value (millions of GBP) & 611 & 109.06 & 4.38 & 3,013 & 105.44 & 6.62 & $(0.939)$ & $(0.000)^{* * * * *}$ \\
\hline Largest Institutional Investor & 557 & 8.04 & 6.41 & 2,732 & 9.13 & 8.12 & $(0.000)^{* * *}$ & $(0.000)^{* * * *}$ \\
\hline Top 5 Institutional Ownership & 557 & 21.62 & 19.64 & 2,732 & 24.84 & 25.31 & $(0.000)^{* * *}$ & $(0.000)^{* * * *}$ \\
\hline Domestic Institutional Ownership & 557 & 33.52 & 33.04 & 2,732 & 40.69 & 42.3 & $(0.000)^{* * *}$ & $(0.000)^{* * *}$ \\
\hline Foreign Institutional Ownership & 557 & 11.68 & 7.09 & 2,732 & 9.48 & 4.69 & $(0.000)^{* * *}$ & $(0.000)^{* * *}$ \\
\hline Total Institutional Ownership & 557 & 45.21 & 48.44 & 2,732 & 50.17 & 54.61 & $(0.000)^{* * *}$ & $(0.000)^{* * *}$ \\
\hline Low-turnover Institutional Ownership & 557 & 33.77 & 32.45 & 2,732 & 38.29 & 40.42 & $(0.000)^{* * *}$ & $(0.000)^{* * * *}$ \\
\hline Moderate-turnover Institutional Ownership & 557 & 6.01 & 5.08 & 2,732 & 7.04 & 5.92 & $(0.000)^{* * *}$ & $(0.002)^{* * * *}$ \\
\hline High-turnover Institutional Ownership & 557 & 1.08 & 0.49 & 2,732 & 1.18 & 0.35 & $(0.261)$ & $(0.062)^{*}$ \\
\hline Firm Size & 579 & 5.62 & 5.65 & 2,758 & 5.20 & 5.21 & $(0.000)^{* * *}$ & $(0.000)^{* * * *}$ \\
\hline ROA & 579 & 0.01 & 0.05 & 2,756 & 0.00 & 0.05 & $(0.309)$ & $(0.903)$ \\
\hline Leverage & 578 & 0.17 & 0.15 & 2,737 & 0.18 & 0.15 & $(0.420)$ & $(0.470)$ \\
\hline Long-term Leverage & 578 & 0.12 & 0.08 & 2,742 & 0.13 & 0.09 & $(0.144)$ & $(0.335)$ \\
\hline Cash \& Equivalent & 579 & 0.16 & 0.09 & 2,758 & 0.15 & 0.10 & $(0.469)$ & $(0.994)$ \\
\hline Capital Expenditures & 562 & 0.05 & 0.04 & 2,709 & 0.04 & 0.03 & $(0.102)$ & $(0.007)^{* * * *}$ \\
\hline Intangible Assets & 579 & 0.24 & 0.15 & 2,755 & 0.26 & 0.22 & $(0.046)^{* *}$ & $(0.005)^{* * * *}$ \\
\hline Dividend Yield & 556 & 2.31 & 1.86 & 2,689 & 2.21 & 1.88 & $(0.353)$ & $(0.592)$ \\
\hline Share Turnover & 541 & 0.97 & 0.79 & 2,573 & 0.85 & 0.68 & $(0.002)^{* * *}$ & $(0.012)^{* *}$ \\
\hline Tobin's q & 559 & 1.75 & 1.30 & 2,655 & 1.74 & 1.21 & $(0.907)$ & $(0.133)$ \\
\hline Target Firm Size & 306 & 4.00 & 3.89 & 1,414 & 3.35 & 3.29 & $(0.000)^{* * *}$ & $(0.000)^{* * *}$ \\
\hline Target Firm Industry-Relative Size & 212 & 0.10 & 0.09 & 534 & 0.12 & 0.11 & $(0.022)^{* *}$ & $(0.009)^{* * * *}$ \\
\hline
\end{tabular}

This table presents descriptive statistics of the continuous variables employed in this study for the two sub-groups of target firms: partial control and full control following the M\&A. Full control is defined as an M\&A bid is for 100\% of target firm's shares (percentage sought), following Ferreira et al., (2010). Otherwise it is classified as Partial control. The variables are defined as in Table 1. All accounting data are taken at year-end prior to the M\&A deal announcement. Test of difference in means (medians) reports the p-values for the homogeneity test for means (medians) assuming unequal variances across the two target groups: partial control and full control. ***, **, and * represent significance at $1 \%, 5 \%$, and $10 \%$, respectively. 
Table 7: Univariate analysis on small vs. large M\&A deals.

\begin{tabular}{|c|c|c|c|c|c|c|c|c|}
\hline \multirow[b]{2}{*}{ Variables } & \multicolumn{3}{|c|}{ Small M\&As } & \multicolumn{3}{|c|}{ Large M\&As } & \multirow{2}{*}{$\begin{array}{c}\text { Test of } \\
\text { difference } \\
\text { in means }\end{array}$} & \multirow{2}{*}{$\begin{array}{c}\text { Test of } \\
\text { difference } \\
\text { in medians }\end{array}$} \\
\hline & $\mathbf{N}$ & Mean & Median & $\mathbf{N}$ & Mean & Median & & \\
\hline Deal Value (millions of GBP) & 1,849 & 2.30 & 1.98 & 1,848 & 208.41 & 22.36 & $(0.004)^{* * * *}$ & $(0.000)^{* * *}$ \\
\hline Largest Institutional Investor & 1,658 & 9.20 & 8.15 & 1,697 & 8.67 & 7.41 & $(0.012)^{* *}$ & $(0.024)^{* * *}$ \\
\hline Top 5 Institutional Ownership & 1,658 & 23.99 & 24.37 & 1,697 & 24.55 & 24.10 & $(0.235)$ & $(0.441)$ \\
\hline Domestic Institutional Ownership & 1,658 & 36.10 & 34.07 & 1,697 & 42.43 & 43.97 & $(0.000)^{* * *}$ & $(0.000)^{* * *}$ \\
\hline Foreign Institutional Ownership & 1,658 & 6.99 & 2.24 & 1,697 & 13.03 & 8.56 & $(0.000)^{* * *}$ & $(0.000)^{* * *}$ \\
\hline Total Institutional Ownership & 1,658 & 43.10 & 42.00 & 1,697 & 55.46 & 60.51 & $(0.000)^{* * *}$ & $(0.000)^{* * *}$ \\
\hline Low-turnover Institutional Ownership & 1,658 & 32.29 & 29.84 & 1,697 & 42.66 & 44.97 & $(0.000)^{* * *}$ & $(0.000)^{* * *}$ \\
\hline Moderate-turnover Institutional Ownership & 1,658 & 6.22 & 4.63 & 1,697 & 7.50 & 6.48 & $(0.000)^{* * *}$ & $(0.000)^{* * *}$ \\
\hline High-turnover Institutional Ownership & 1,658 & 1.03 & 0.15 & 1,697 & 1.29 & 0.62 & $(0.001)^{* * *}$ & $(0.000)^{* * *}$ \\
\hline Firm Size & 1,686 & 4.81 & 4.81 & 1,718 & 5.76 & 5.78 & $(0.000)^{* * *}$ & $(0.000)^{* * *}$ \\
\hline ROA & 1,686 & -0.03 & 0.04 & 1,716 & 0.03 & 0.05 & $(0.000)^{* * *}$ & $(0.000)^{* * *}$ \\
\hline Leverage & 1,670 & 0.15 & 0.12 & 1,712 & 0.20 & 0.18 & $(0.000)^{* * *}$ & $(0.000)^{* * * *}$ \\
\hline Long-term Leverage & 1,672 & 0.10 & 0.04 & 1,715 & 0.16 & 0.12 & $(0.000)^{* * *}$ & $(0.000)^{* * *}$ \\
\hline Cash \& Equivalent & 1,686 & 0.17 & 0.11 & 1,718 & 0.14 & 0.08 & $(0.000)^{* * *}$ & $(0.000)^{* * * *}$ \\
\hline Capital Expenditures & 1,648 & 0.04 & 0.02 & 1,690 & 0.05 & 0.04 & $(0.013)^{* *}$ & $(0.000)^{* * *}$ \\
\hline Intangible Assets & 1,684 & 0.26 & 0.20 & 1,717 & 0.26 & 0.21 & $(0.662)$ & $(0.081)^{*}$ \\
\hline Dividend Yield & 1,625 & 2.06 & 1.48 & 1,685 & 2.37 & 2.13 & $(0.000)^{* * *}$ & $(0.000)^{* * *}$ \\
\hline Share Turnover & 1,544 & 0.70 & 0.49 & 1,634 & 1.03 & 0.92 & $(0.000)^{* * *}$ & $(0.000)^{* * *}$ \\
\hline Tobin's q & 1,612 & 1.64 & 1.18 & 1,669 & 1.86 & 1.29 & $(0.001)^{* * *}$ & $(0.000)^{* * * *}$ \\
\hline Target Firm Size & 993 & 3.02 & 3.06 & 747 & 4.06 & 3.92 & $(0.000)^{* * *}$ & $(0.000)^{* * *}$ \\
\hline Target Firm Industry-Relative Size & 311 & 0.10 & 0.08 & 457 & 0.12 & 0.12 & $(0.003)^{* * *}$ & $(0.007)^{* * *}$ \\
\hline
\end{tabular}

This table presents descriptive statistics of the continuous variables employed in this study for the two sub-groups of target firms: small M\&As and large M\&As. M\&A deals are classified as small if their value is lower than the median deal value of our sample. M\&A deals are classified as large deals if they are equal or higher than the median deal size of our sample. The variables are defined as in Table 1. All accounting data are taken at year-end prior to the M\&A deal announcement. Test of difference in means (medians) reports the p-values for the homogeneity test for means (medians) assuming unequal variances across the two target groups: small M\&As and large M\&As. ***, **, and $*$ represent significance at $1 \%, 5 \%$, and $10 \%$, respectively. 
Table 8: Probit analysis of UK acquirers conducting a cross-border M\&A.

\begin{tabular}{|c|c|c|c|c|c|}
\hline & \multicolumn{2}{|c|}{$1^{\text {st }}$ stage Probit } & \multicolumn{3}{|c|}{$\begin{array}{c}\mathbf{2}^{\text {nd }} \text { stage Probit } \\
\text { Endogeneity adjusted }\end{array}$} \\
\hline & (1) & (2) & (3) & (4) & (5) \\
\hline Cross Industry & $\begin{array}{l}-0.592^{*} \\
(-1.93)\end{array}$ & $\begin{array}{l}-0.194 \\
(-1.56)\end{array}$ & $\begin{array}{l}0.078 \\
(1.21)\end{array}$ & $\begin{array}{l}-0.025 \\
(-0.32)\end{array}$ & \\
\hline Listed Target & & $\begin{array}{l}0.089 \\
(0.29)\end{array}$ & $\begin{array}{l}0.090 \\
(0.70)\end{array}$ & $\begin{array}{l}-0.182 \\
(-1.15)\end{array}$ & \\
\hline Initial Stake & & $\begin{array}{l}0.003 \\
(0.66)\end{array}$ & & & $\begin{array}{l}0.003 \\
(1.37)\end{array}$ \\
\hline Cash Payment & & $\begin{array}{l}-0.109 \\
(-0.68)\end{array}$ & & & $\begin{array}{c}-0.180^{* * *} \\
(-2.66)\end{array}$ \\
\hline Share Payment & & $\begin{array}{l}0.050 \\
(0.29)\end{array}$ & $\begin{array}{l}0.152^{* *} \\
(2.13)\end{array}$ & & \\
\hline Financial Crisis & $\begin{array}{l}-0.524^{*} \\
(-1.61)\end{array}$ & $\begin{array}{l}0.099 \\
(0.94)\end{array}$ & & & $\begin{array}{c}-0.192^{* * *} \\
(-2.74)\end{array}$ \\
\hline Largest Institutional Ownership & & $\begin{array}{l}0.006 \\
(0.40)\end{array}$ & & & \\
\hline Top 5 Institutional Ownership & & $\begin{array}{l}-0.001^{* *} \\
(-0.07)\end{array}$ & $\begin{array}{l}0.088^{* * *} \\
(34.91)\end{array}$ & & \\
\hline Foreign Institutional Ownership & & $\begin{array}{l}0.010 \\
(2.17)\end{array}$ & & $\begin{array}{l}0.089^{* * * *} \\
(13.35)\end{array}$ & \\
\hline Total Institutional Ownership & & $\begin{array}{l}0.013 \\
(1.63)\end{array}$ & & & $\begin{array}{l}0.043^{* * *} \\
(29.63)\end{array}$ \\
\hline Low-turnover Institutional Ownership & & $\begin{array}{l}-0.008 \\
(-1.11)\end{array}$ & & $\begin{array}{l}-0.023^{* * *} \\
(-12.34)\end{array}$ & \\
\hline Moderate-turnover Institutional Ownership & & $\begin{array}{l}-0.022^{*} \\
(-1.77)\end{array}$ & $\begin{array}{c}-0.077^{* * *} \\
(-8.54)\end{array}$ & & \\
\hline High-turnover Institutional Ownership & & $\begin{array}{l}0.009 \\
(0.38)\end{array}$ & $\begin{array}{c}-0.055^{* * *} \\
(-3.45)\end{array}$ & & \\
\hline M\&A Experience & $\begin{array}{l}0.780^{*} \\
(1.64)\end{array}$ & $\begin{array}{l}0.043 \\
(0.30)\end{array}$ & & & \\
\hline Target Firm Size & & $\begin{array}{c}0.384^{* * * *} \\
(4.77)\end{array}$ & & & \\
\hline Target Firm Industry-Relative Size & $\begin{array}{l}0.209^{* * *} \\
(3.34)\end{array}$ & & & & \\
\hline Cons. & $\begin{array}{l}1.490^{* * *} \\
(2.49)\end{array}$ & $\begin{array}{c}-8.612^{\text {**** }} \\
(-8.18)\end{array}$ & $\begin{array}{l}-1.864^{* * *} \\
(-10.05)\end{array}$ & $\begin{array}{l}0.790 \\
(0.06)\end{array}$ & $\begin{array}{l}13.110 \\
(1.19)\end{array}$ \\
\hline Firm specific control variables & $\sqrt{ }$ & $\sqrt{ }$ & $\sqrt{ }$ & $\sqrt{ }$ & $\sqrt{ }$ \\
\hline Industry/Year controls & $\sqrt{ }$ & $\sqrt{ }$ & $\sqrt{ }$ & $\sqrt{ }$ & $\sqrt{ }$ \\
\hline Obs. & 731 & 1,285 & 3,060 & 2,624 & 3,061 \\
\hline Pseudo R $(\%)$ & 79.76 & 23.67 & & & \\
\hline $\begin{array}{l}\text { Log pseudo-likelihood } \\
\text { Wald } \operatorname{chi}^{2}(1) \\
\text { p-value Wald test }\end{array}$ & & & $\begin{array}{c}-13,267.2 \\
65.84 \\
(0.000)\end{array}$ & $\begin{array}{c}-13,213.7 \\
52.51 \\
(0.000)\end{array}$ & $\begin{array}{c}-13,281.4 \\
73.57 \\
(0.000)\end{array}$ \\
\hline Correctly classified (\%) & 96.72 & 81.01 & 50.42 & 52.44 & 60.47 \\
\hline
\end{tabular}


This table presents the results of probit regressions for estimating the probability of UK bidders choosing a cross-border target. The sample comprises 3,821 M\&As undertaken by UK listed firms announced between $01 / 01 / 2000$ and $31 / 12 / 2010$. The dependent variable is a dummy variable which equals to 1 when the deal is a cross-border deal, and 0 for domestic deals. The variables are defined as in Table 1. All accounting data are taken at year-end prior to the M\&A deal announcement. Z-statistics based on clusteradjusted robust standard errors (Petersen, 2009, hence providing robust interpretations (Cameron et al., 2008)) are reported in parentheses. Correctly classified (\%) compares the fitted and actual values based on a 0.50 cut-off point ${ }^{* *}$, $* *$, and $*$ represent significance at $1 \%, 5 \%$, and $10 \%$, respectively. 
Table 9: Probit regressions on taking full control of target firms following the M\&A.

\begin{tabular}{|c|c|c|c|c|c|c|c|c|}
\hline & \multicolumn{4}{|c|}{$1^{\text {st }}$ stage Probit } & \multicolumn{4}{|c|}{$2^{\text {nd }}$ stage Probit - Endogeneity adjusted } \\
\hline & (1) & $(2)$ & (3) & (4) & (5) & (6) & (7) & (8) \\
\hline Cross-Border & $\begin{array}{c}-0.314 * * * \\
(-3.81)\end{array}$ & $\begin{array}{c}-0.392 * * * \\
(-3.07)\end{array}$ & $\begin{array}{c}-0.391 * * * \\
(-3.01)\end{array}$ & $\begin{array}{l}-0.313 \\
(-0.99)\end{array}$ & $\begin{array}{l}0.016 \\
(0.15)\end{array}$ & $\begin{array}{c}-0.663 * \\
(-1.78)\end{array}$ & $\begin{array}{l}-0.246 \\
(-1.40)\end{array}$ & $\begin{array}{c}-0.315 * * \\
(-2.29)\end{array}$ \\
\hline Cross Industry & $\begin{array}{c}-0.172 * * \\
(-2.15)\end{array}$ & $\begin{array}{l}-0.026 \\
(-0.22)\end{array}$ & $\begin{array}{l}-0.035 \\
(-0.29)\end{array}$ & $\begin{array}{l}-0.162 \\
(-1.06)\end{array}$ & $\begin{array}{c}-0.138^{*} \\
(-1.80)\end{array}$ & $\begin{array}{c}-0.258^{*} \\
(-1.88)\end{array}$ & $\begin{array}{c}-0.146^{*} \\
(-1.84)\end{array}$ & \\
\hline Listed Target & $\begin{array}{c}-2.392 * * * \\
(-7.66)\end{array}$ & $\begin{array}{c}-2.833 * * * \\
(-5.88)\end{array}$ & $\begin{array}{c}-2.818 * * * \\
(-5.93)\end{array}$ & $\begin{array}{c}-2.940 * * * \\
(-5.00)\end{array}$ & $\begin{array}{l}-0.345 \\
(-0.45)\end{array}$ & & $\begin{array}{l}-0.181 \\
(-0.17)\end{array}$ & \\
\hline Initial Stake & $\begin{array}{c}-0.011 * * * \\
(-5.83)\end{array}$ & $\begin{array}{c}-0.012 * * * \\
(-5.69)\end{array}$ & $\begin{array}{c}-0.012 * * * \\
(-5.50)\end{array}$ & $\begin{array}{c}-0.008^{* *} \\
(-2.19)\end{array}$ & $\begin{array}{l}-0.003 \\
(-0.95)\end{array}$ & $\begin{array}{l}-0.003 \\
(-0.68)\end{array}$ & $\begin{array}{l}-0.005 \\
(-1.02)\end{array}$ & \\
\hline Cash Payment & $\begin{array}{l}-0.126 \\
(-0.83)\end{array}$ & $\begin{array}{c}-0.590 * * \\
(-2.41)\end{array}$ & $\begin{array}{c}-0.609 * * \\
(-2.48)\end{array}$ & & $\begin{array}{l}0.038 \\
(0.39)\end{array}$ & $\begin{array}{l}-0.012 \\
(-0.08)\end{array}$ & $\begin{array}{l}-0.050 \\
(-0.46)\end{array}$ & $\begin{array}{l}-0.176 \\
(-1.26)\end{array}$ \\
\hline Share Payment & $\begin{array}{l}-0.217 \\
(-1.26)\end{array}$ & $\begin{array}{c}-0.590 * * \\
(-2.15)\end{array}$ & $\begin{array}{c}-0.614 * * \\
(-2.23)\end{array}$ & $\begin{array}{l}0.265 \\
(1.24)\end{array}$ & $\begin{array}{l}0.022 \\
(0.16)\end{array}$ & & $\begin{array}{l}0.127 \\
(1.00)\end{array}$ & $\begin{array}{l}-0.188 \\
(-1.24)\end{array}$ \\
\hline Financial Crisis & $\begin{array}{c}-0.194 * * \\
(-2.17)\end{array}$ & $\begin{array}{c}-0.221^{*} \\
(-1.89)\end{array}$ & $\begin{array}{l}-0.187 \\
(-1.62)\end{array}$ & $\begin{array}{l}-0.196 \\
(-1.17)\end{array}$ & & & $\begin{array}{l}-0.043 \\
(-0.37)\end{array}$ & $\begin{array}{l}-0.029 \\
(-0.19)\end{array}$ \\
\hline Largest Institutional Ownership & & & & & & $\begin{array}{c}-0.171^{*} \\
(-1.94)\end{array}$ & $\begin{array}{c}-0.191 * * * \\
(-16.10)\end{array}$ & $\begin{array}{l}-0.013 \\
(-0.90)\end{array}$ \\
\hline Top 5 Institutional Ownership & & & & & $\begin{array}{c}-0.125^{* * *} \\
(-17.21)\end{array}$ & & & \\
\hline Foreign Institutional Ownership & $\begin{array}{l}-0.005 \\
(-1.24)\end{array}$ & $\begin{array}{l}-0.008 \\
(-1.41)\end{array}$ & $\begin{array}{l}-0.005 \\
(-1.00)\end{array}$ & $\begin{array}{c}-0.011^{*} \\
(-1.95)\end{array}$ & & & & $\begin{array}{c}0.093 * * \\
(2.54)\end{array}$ \\
\hline Total Institutional Ownership & $\begin{array}{l}0.002 \\
(0.35)\end{array}$ & $\begin{array}{l}0.005 \\
(0.66)\end{array}$ & $\begin{array}{c}0.006^{* *} \\
(2.24)\end{array}$ & $\begin{array}{c}0.010 * * * \\
(3.07)\end{array}$ & & & & \\
\hline Low-turnover Institutional Ownership & $\begin{array}{l}0.005 \\
(0.82)\end{array}$ & $\begin{array}{l}-0.002 \\
(-0.29)\end{array}$ & & & $\begin{array}{c}0.058 * * * \\
(14.52)\end{array}$ & $\begin{array}{c}0.021^{*} \\
(1.90)\end{array}$ & $\begin{array}{c}0.023 * * * \\
(11.56)\end{array}$ & $\begin{array}{l}-0.004 \\
(-0.39)\end{array}$ \\
\hline Moderate-turnover Institutional Ownership & $\begin{array}{l}0.009 \\
(0.99)\end{array}$ & $\begin{array}{l}0.018 \\
(1.54)\end{array}$ & & & $\begin{array}{c}0.051 * * * \\
(4.68)\end{array}$ & $\begin{array}{c}0.049 * * * \\
(2.92)\end{array}$ & $\begin{array}{c}0.018 * \\
(1.78)\end{array}$ & $\begin{array}{l}-0.015 \\
(-0.81)\end{array}$ \\
\hline High-turnover Institutional Ownership & $\begin{array}{l}0.030 \\
(1.57)\end{array}$ & $\begin{array}{l}0.034 \\
(1.04)\end{array}$ & & & $\begin{array}{c}0.080 * * * \\
(3.88)\end{array}$ & $\begin{array}{l}0.047 \\
(1.49)\end{array}$ & $\begin{array}{c}0.040^{*} \\
(1.66)\end{array}$ & $\begin{array}{l}-0.055 \\
(-1.17)\end{array}$ \\
\hline M\&A Experience & $\begin{array}{l}-0.014 \\
(-0.16)\end{array}$ & $\begin{array}{l}0.072 \\
(0.50)\end{array}$ & $\begin{array}{l}0.066 \\
(0.46)\end{array}$ & $\begin{array}{l}-0.131 \\
(-0.66)\end{array}$ & $\begin{array}{l}0.004 \\
(0.06)\end{array}$ & $\begin{array}{l}-0.150 \\
(-0.69)\end{array}$ & $\begin{array}{c}-0.307 * * * \\
(-4.99)\end{array}$ & $\begin{array}{l}0.132 \\
(1.58)\end{array}$ \\
\hline Target Firm size & & $\begin{array}{l}-0.030 \\
(-0.40)\end{array}$ & $\begin{array}{l}-0.031 \\
(-0.41)\end{array}$ & & & & & \\
\hline Target Firm Industry-Relative Size & & & & $-1.494 *$ & & $-1.483^{*}$ & & \\
\hline
\end{tabular}




\begin{tabular}{|c|c|c|c|c|c|c|c|c|}
\hline & & & & $(-1.91)$ & & $(-1.75)$ & & \\
\hline Cons. & $\begin{array}{c}1.787 * * * \\
(4.53)\end{array}$ & $\begin{array}{c}5.458 * * * \\
(10.70)\end{array}$ & $\begin{array}{c}5.683 * * * \\
(11.56)\end{array}$ & $\begin{array}{c}1.142 * * \\
(2.02)\end{array}$ & $\begin{array}{c}4.515 * * * \\
(9.52)\end{array}$ & $\begin{array}{c}3.087 * * * \\
(7.42)\end{array}$ & $\begin{array}{c}1.331 * * \\
(2.54)\end{array}$ & $\begin{array}{c}3.147 * * * \\
(4.71)\end{array}$ \\
\hline Firm specific control variables & $\sqrt{ }$ & $\sqrt{ }$ & $\sqrt{ }$ & $\sqrt{ }$ & $\sqrt{ }$ & $\sqrt{ }$ & $\sqrt{ }$ & $\sqrt{ }$ \\
\hline Industry/Year controls & $\sqrt{ }$ & $\sqrt{ }$ & $\sqrt{ }$ & $\sqrt{ }$ & $\sqrt{ }$ & $\sqrt{ }$ & $\sqrt{ }$ & $\sqrt{ }$ \\
\hline Obs. & 2,734 & 1,317 & 1,317 & 639 & 2,576 & 485 & 2,868 & 2,596 \\
\hline Pseudo $R^{2}(\%)$ & 20.92 & 27.33 & 26.91 & 28.57 & & & & \\
\hline Log pseudo-likelihood & & & & & $-9,889.6$ & $-1,638.7$ & $-9,826.2$ & $-10,578.5$ \\
\hline Wald $\operatorname{chi}^{2}(1)$ & & & & & 2.93 & 0.98 & 0.63 & 0.81 \\
\hline p-value Wald test & & & & & $(0.087)$ & $(0.322)$ & $(0.427)$ & $(0.368)$ \\
\hline Correctly classified (\%) & 86.14 & 87.02 & 86.71 & 80.59 & 62.27 & 72.58 & 58.23 & 65.22 \\
\hline
\end{tabular}

This table presents the results of probit regressions for estimating the probability of UK bidders acquiring full control of the target firm, based on 3,821 M\&As undertaken by UK listed firms from 01/01/2000 to 31/12/2010. The dependent variable is a dummy variable which equals to 1 when the M\&As result in a full control $(100 \%)$ of the target firm and 0 otherwise. The variables are defined as in Table 1 . All accounting data are taken at year-end prior to the M\&A deal announcement. Z-statistics based on cluster-adjusted robust standard errors (Petersen, 2009, hence providing robust interpretations (Cameron et al., 2008)) are reported in parentheses. Correctly classified (\%) compares the fitted and actual values based on a 0.50 cut-off point $* * *, * *$, and $*$ represent significance at $1 \%, 5 \%$, and $10 \%$, respectively. 
Table 10: Tobit regressions on M\&As deal size

\begin{tabular}{|c|c|c|c|c|c|c|}
\hline & (1) & (2) & (3) & (4) & (5) & $(6)$ \\
\hline Cross-border & & $\begin{array}{c}0.738 * * * \\
(10.60)\end{array}$ & & $\begin{array}{l}0.368 * * * \\
(5.71)\end{array}$ & $\begin{array}{l}0.516^{* * *} \\
\quad(4.75)\end{array}$ & $\begin{array}{c}0.253 * * \\
(2.34)\end{array}$ \\
\hline Cross Industry & & & $\begin{array}{c}-0.290 * * * \\
(-2.12)\end{array}$ & $\begin{array}{c}-0.306^{* * *} \\
(-4.94)\end{array}$ & $\begin{array}{c}-0.312 * * * \\
(-3.22)\end{array}$ & $\begin{array}{c}-0.173^{*} \\
(-1.92)\end{array}$ \\
\hline Listed Target & & $\begin{array}{l}-0.152 \\
(-0.84)\end{array}$ & $\begin{array}{c}-0.971 * * * \\
(-4.14)\end{array}$ & $\begin{array}{c}-0.624 * * * \\
(-3.64)\end{array}$ & $\begin{array}{c}-0.879 * * * \\
(-2.78)\end{array}$ & $\begin{array}{c}-1.617 * * * \\
(-6.20)\end{array}$ \\
\hline Initial Stake & $\begin{array}{l}-0.190 \\
(-1.60)\end{array}$ & & & $\begin{array}{c}-0.522 * * * \\
(-4.92)\end{array}$ & $\begin{array}{c}-0.011 * * \\
(-2.41)\end{array}$ & $\begin{array}{c}-0.017 * * * \\
(-4.05)\end{array}$ \\
\hline Cash Payment & & & & & $\begin{array}{c}0.200^{*} \\
(1.90)\end{array}$ & $\begin{array}{c}-0.245^{* *} \\
(-2.07)\end{array}$ \\
\hline Share Payment & & & & & $\begin{array}{l}0.419 * * * \\
(2.92)\end{array}$ & $\begin{array}{l}-0.102 \\
(-0.71)\end{array}$ \\
\hline Financial Crisis & $\begin{array}{c}-0.243^{* * *} \\
(-2.99)\end{array}$ & & & $\begin{array}{l}0.058 \\
(0.79)\end{array}$ & $\begin{array}{l}-0.104 \\
(-1.06)\end{array}$ & $\begin{array}{l}-0.022 \\
(-0.23)\end{array}$ \\
\hline Largest Institutional investor & & & & $\begin{array}{l}0.003 \\
(0.28)\end{array}$ & $\begin{array}{c}-0.042 * * * \\
(-4.18)\end{array}$ & $\begin{array}{c}-0.032 * * * \\
(-3.78)\end{array}$ \\
\hline Top 5 Institutional Ownership & $\begin{array}{c}-0.010 * * * \\
(-3.76)\end{array}$ & & & $\begin{array}{l}-0.005 \\
(0.69)\end{array}$ & & \\
\hline Foreign Institutional Ownership & $\begin{array}{c}0.031 * * * \\
(10.34)\end{array}$ & & & $\begin{array}{l}0.001 \\
(0.49)\end{array}$ & $\begin{array}{c}0.019 * * * \\
(3.74)\end{array}$ & $\begin{array}{l}0.002 \\
(0.38)\end{array}$ \\
\hline Total Institutional Ownership & & & & $\begin{array}{l}0.008^{* *} \\
(2.05)\end{array}$ & & \\
\hline $\begin{array}{l}\text { Low-turnover } \\
\text { Institutional Ownership }\end{array}$ & & $\begin{array}{c}0.010 * * * \\
(6.37)\end{array}$ & & $\begin{array}{l}0.002 \\
(0.59)\end{array}$ & $\begin{array}{c}0.014 * * * \\
(4.66)\end{array}$ & $\begin{array}{l}0.005^{*} \\
(1.69)\end{array}$ \\
\hline $\begin{array}{l}\text { Moderate-turnover } \\
\text { Institutional Ownership }\end{array}$ & & & & $\begin{array}{l}0.003 \\
(0.52)\end{array}$ & $\begin{array}{l}-0.006 \\
(-0.54)\end{array}$ & $\begin{array}{l}0.014^{*} \\
(1.76)\end{array}$ \\
\hline $\begin{array}{l}\text { High-turnover } \\
\text { Institutional Ownership }\end{array}$ & & & & $\begin{array}{l}0.003 \\
(0.22)\end{array}$ & $\begin{array}{l}-0.008 \\
(-0.28)\end{array}$ & $\begin{array}{l}-0.003 \\
(-0.13)\end{array}$ \\
\hline M\&A Experience & & & $\begin{array}{c}0.478 * * * \\
(2.72)\end{array}$ & & & \\
\hline Target Firm Size & & & & & & $\begin{array}{c}1.235^{* * *} \\
(18.02)\end{array}$ \\
\hline $\begin{array}{l}\text { Target Firm Industry- } \\
\text { Relative Size }\end{array}$ & & & $\begin{array}{l}0.001 \\
(0.25)\end{array}$ & & & \\
\hline Cons. & $\begin{array}{c}1.164 * * * \\
(11.32)\end{array}$ & $\begin{array}{c}0.587 * * * \\
(6.13)\end{array}$ & $\begin{array}{l}2.111 * * * \\
(10.79)\end{array}$ & $\begin{array}{c}-4.339 * * * \\
(-17.19)\end{array}$ & $\begin{array}{c}1.694 * * * \\
(42.27)\end{array}$ & $\begin{array}{c}1.222 * * * \\
(33.10)\end{array}$ \\
\hline Firm specific control variables & $\sqrt{ }$ & $\sqrt{ }$ & $\sqrt{ }$ & $\sqrt{ }$ & $\sqrt{ }$ & $\sqrt{ }$ \\
\hline Industry/Year controls & $\sqrt{ }$ & $\sqrt{ }$ & $\sqrt{ }$ & $\sqrt{ }$ & $\sqrt{ }$ & $\sqrt{ }$ \\
\hline Obs. & 2,918 & 3,023 & 768 & 2,918 & 2,635 & 1,283 \\
\hline Pseudo. $R^{2}(\%)$ & 3.98 & 4.09 & 1.06 & 10.07 & 7.61 & 12.24 \\
\hline
\end{tabular}

This table presents the results of Tobit regressions for estimating the determinants of the deal size for cross-border M\&As undertaken by UK bidders. The sample comprises 3,821 M\&As undertaken by UK listed firms announced between 01/01/2000 and 31/12/2010. The dependent variable is Deal Size, measured as the natural logarithm of the deal value. We use a lower bound of $£ 0.1 \mathrm{~m}$ as it is one of the restrictions imposed during the sample selection process. The variables are defined as in Table 1. All accounting data are taken at year-end prior to the M\&A deal announcement. Z-statistics based on cluster-adjusted robust standard errors (Petersen, 2009, hence providing robust interpretations (Cameron et al., 2008)) are reported in parentheses. Correctly classified (\%) compares the fitted and actual values based on a 0.50 cut-off point $* * *, * *$, and $*$ represent significance at $1 \%, 5 \%$, and $10 \%$, respectively. 
Table 11: Shareholder returns surrounding the M\&A announcement returns.

Panel A. Average returns for varying $M \& A$ deal types.

\begin{tabular}{|c|c|c|c|c|c|c|c|c|c|c|}
\hline & & $\begin{array}{c}\text { Domestic } \\
\text { M\&As }\end{array}$ & $\begin{array}{c}\text { Cross- } \\
\text { border } \\
\text { M\&As }\end{array}$ & $\begin{array}{c}\text { Small } \\
\text { M\&As }\end{array}$ & $\begin{array}{c}\text { Large } \\
\text { M\&As }\end{array}$ & $\begin{array}{c}\text { Large } \\
\text { Domestic } \\
\text { M\&As }\end{array}$ & $\begin{array}{l}\text { Large } \\
\text { Cross- } \\
\text { Border } \\
\text { M\&As }\end{array}$ & $\begin{array}{c}\text { Small } \\
\text { Domestic } \\
\text { M\&As }\end{array}$ & $\begin{array}{c}\text { Small } \\
\text { Cross- } \\
\text { Border } \\
\text { M\&As }\end{array}$ & All M\&As \\
\hline \multirow[t]{4}{*}{ CAR-1,+1 } & Mean & $0.75 \%$ & $0.33 \%$ & $0.67 \%$ & $0.50 \%$ & $0.80 \%$ & $0.72 \%$ & $0.30 \%$ & $0.38 \%$ & $0.59 \%$ \\
\hline & $p$-value & \multicolumn{2}{|c|}{$(0.001)^{* * *}$} & \multicolumn{2}{|c|}{ (0.198) } & \multicolumn{2}{|c|}{$(0.675)$} & \multicolumn{2}{|c|}{$(0.639)$} & \\
\hline & Obs. & 2,123 & 1,374 & 1,751 & 1,746 & 838 & 1,285 & 812 & 562 & 3,497 \\
\hline & $\mathrm{SD}$ & $4.35 \%$ & $2.96 \%$ & $3.91 \%$ & $3.83 \%$ & $4.59 \%$ & $4.19 \%$ & $2.49 \%$ & $3.53 \%$ & $3.87 \%$ \\
\hline \multirow[t]{4}{*}{ CAR- $10,+10$} & Mean & $0.48 \%$ & $0.22 \%$ & $0.54 \%$ & $0.22 \%$ & $0.49 \%$ & $0.48 \%$ & $0.02 \%$ & $0.49 \%$ & $0.38 \%$ \\
\hline & $p$-value & \multicolumn{2}{|c|}{$(0.266)$} & \multicolumn{2}{|c|}{$(0.195)$} & \multicolumn{2}{|c|}{$(0.983)$} & \multicolumn{2}{|c|}{$(0.194)$} & \\
\hline & Obs. & 2,123 & 1,374 & 1,751 & 1,746 & 838 & 1,285 & 812 & 562 & 3,497 \\
\hline & $\mathrm{SD}$ & $7.86 \%$ & $6.30 \%$ & $7.75 \%$ & $6.78 \%$ & $7.36 \%$ & $8.17 \%$ & $5.55 \%$ & $7.24 \%$ & $7.28 \%$ \\
\hline \multirow[t]{4}{*}{ CAR-1,+20 } & Mean & $0.02 \%$ & $-0.20 \%$ & $0.19 \%$ & $-0.32 \%$ & $-0.12 \%$ & $0.11 \%$ & $-0.42 \%$ & $0.12 \%$ & $-0.07 \%$ \\
\hline & $p$-value & \multicolumn{2}{|c|}{$(0.510)$} & \multicolumn{2}{|c|}{$(0.138)$} & \multicolumn{2}{|c|}{$(0.611)$} & \multicolumn{2}{|c|}{$(0.278)$} & \\
\hline & Obs. & 2,123 & 1,374 & 1,751 & 1,746 & 838 & 1,285 & 812 & 562 & 3,497 \\
\hline & $\mathrm{SD}$ & $10.76 \%$ & $8.82 \%$ & $10.77 \%$ & $9.25 \%$ & $10.04 \%$ & $11.21 \%$ & $8.00 \%$ & $9.88 \%$ & $10.04 \%$ \\
\hline \multirow[t]{4}{*}{ CAR-20,-2 } & Mean & $-0.25 \%$ & $-0.19 \%$ & $-0.24 \%$ & $-0.21 \%$ & $-0.15 \%$ & $-0.32 \%$ & $-0.30 \%$ & $-0.03 \%$ & $-0.23 \%$ \\
\hline & $p$-value & \multicolumn{2}{|c|}{$(0.748)$} & \multicolumn{2}{|c|}{$(0.885)$} & \multicolumn{2}{|c|}{$(0.521)$} & \multicolumn{2}{|c|}{$(0.361)$} & \\
\hline & Obs. & 2,123 & 1,374 & 1,751 & 1,746 & 838 & 1,285 & 812 & 562 & 3,497 \\
\hline & $\mathrm{SD}$ & $6.09 \%$ & $5.16 \%$ & $6.44 \%$ & $4.94 \%$ & $5.31 \%$ & $6.54 \%$ & $4.53 \%$ & $5.96 \%$ & $5.74 \%$ \\
\hline
\end{tabular}


Panel B. The drivers of announcement returns

\begin{tabular}{|c|c|c|c|c|c|c|c|c|c|c|c|c|}
\hline & \multicolumn{4}{|c|}{ CAR $-1,+1$} & \multicolumn{4}{|c|}{ CAR $-10,+10$} & \multicolumn{4}{|c|}{ CAR $-20,-2$} \\
\hline & (1) & $(2)$ & (3) & (4) & (5) & (6) & (7) & (8) & (9) & (10) & (11) & (12) \\
\hline \multirow[t]{2}{*}{ Cross Industry } & 0.001 & & -0.001 & 0.001 & 0.001 & & 0.005 & 0.000 & 0.000 & & 0.005 & 0.001 \\
\hline & $(0.638)$ & & $(-0.500)$ & $(0.370)$ & $(0.304)$ & & $(0.920)$ & $(0.080)$ & $(-0.133)$ & & $(1.150)$ & $(0.200)$ \\
\hline \multirow[t]{2}{*}{ Cross-Border } & $-0.004 * * *$ & 0.003 & 0.002 & $-0.004 *$ & -0.001 & 0.020 & 0.015 & -0.005 & 0.001 & 0.015 & 0.005 & -0.002 \\
\hline & $(-2.816)$ & $(0.440)$ & $(0.280)$ & $(-1.860)$ & $(-0.554)$ & $(1.550)$ & $(1.200)$ & $(-1.310)$ & $(0.445)$ & $(1.180)$ & $(0.410)$ & $(-0.520)$ \\
\hline \multirow[t]{2}{*}{ Listed Target } & 0.001 & & 0.002 & 0.010 & 0.011 & & 0.000 & 0.011 & -0.006 & & -0.011 & $-0.019^{* *}$ \\
\hline & $(0.162)$ & & $(0.230)$ & $(1.180)$ & (1.308) & & $(-0.020)$ & $(0.980)$ & $(-0.798)$ & & $(-1.060)$ & $(-2.290)$ \\
\hline \multirow[t]{2}{*}{ Initial Stake } & & 0.000 & 0.000 & 0.000 & & 0.000 & 0.000 & 0.000 & & 0.000 & 0.000 & 0.000 \\
\hline & & $(-1.060)$ & $(-0.570)$ & $(-0.300)$ & & $(-1.170)$ & $(-0.220)$ & $(-0.510)$ & & $(0.260)$ & $(1.250)$ & $(-0.410)$ \\
\hline \multirow[t]{2}{*}{ Cash Payment } & & 0.002 & & 0.002 & & 0.004 & & $0.007 *$ & & 0.000 & & -0.001 \\
\hline & & $(0.530)$ & & $(0.640)$ & & $(0.480)$ & & $(1.750)$ & & $(-0.070)$ & & $(-0.230)$ \\
\hline \multirow[t]{2}{*}{ Share Payment } & $0.006 * *$ & & & & -0.003 & & & & -0.002 & & & \\
\hline & (2.000) & & & & $(-0.571)$ & & & & $(-0.719)$ & & & \\
\hline \multirow[t]{2}{*}{ Financial Crisis } & $-0.006^{* * *}$ & -0.005 & $-0.005^{*}$ & $-0.006^{* * *}$ & $-0.011 * * *$ & -0.009 & -0.016 & $-0.016^{* * *}$ & $-0.005 * *$ & 0.002 & 0.000 & $-0.011 * * *$ \\
\hline & $(-3.064)$ & $(-1.460)$ & $(-1.840)$ & $(-2.660)$ & $(-3.441)$ & $(-1.160)$ & $(-2.380)$ & $(-3.710)$ & $(-2.027)$ & $(0.360)$ & $(0.000)$ & $(-3.140)$ \\
\hline Largest Institutional & & & & 0.000 & & & & 0.000 & & & & -0.001 \\
\hline Ownership & & & & $(0.930)$ & & & & $(-0.170)$ & & & & $(-1.290)$ \\
\hline Top 5 Institutional & 0.000 & & 0.000 & 0.000 & 0.000 & & 0.000 & 0.000 & 0.000 & & 0.000 & 0.000 \\
\hline Ownership & $(-0.042)$ & & (1.190) & $(-1.050)$ & $(0.845)$ & & $(0.240)$ & $(-0.280)$ & $(0.817)$ & & $(1.350)$ & $(0.570)$ \\
\hline Foreign Institutional & & 0.000 & $0.000 * * *$ & 0.000 & & 0.000 & 0.000 & 0.000 & & 0.000 & 0.000 & 0.000 \\
\hline Ownership & & $(-1.360)$ & $(-2.820)$ & $(0.940)$ & & $(-0.130)$ & $(-1.010)$ & $(1.210)$ & & $(0.220)$ & $(1.130)$ & $(0.240)$ \\
\hline Total Institutional & & $0.000 *$ & & 0.000 & & 0.000 & & $0.000^{*}$ & & 0.000 & & 0.000 \\
\hline Ownership & & $(1.700)$ & & $(-0.400)$ & & $(0.430)$ & & $(-1.780)$ & & $(-0.160)$ & & $(-0.420)$ \\
\hline Low-turnover & & & 0.000 & 0.000 & & & 0.000 & $0.000 * *$ & & & 0.000 & 0.000 \\
\hline Institutional Ownership & & & $(-1.210)$ & $(1.140)$ & & & $(0.450)$ & $(1.960)$ & & & $(-0.920)$ & $(0.600)$ \\
\hline Moderate-turnover & & & 0.000 & 0.001 & & & 0.002 & 0.001 & & & $0.003 * * *$ & 0.000 \\
\hline Institutional Ownership & & & $(0.060)$ & $(1.220)$ & & & $(1.190)$ & $(0.700)$ & & & $(2.410)$ & $(0.230)$ \\
\hline High-turnover & & & 0.000 & -0.001 & & & -0.001 & 0.000 & & & $-0.003 * * *$ & 0.000 \\
\hline Institutional Ownership & & & $(0.180)$ & $(-1.090)$ & & & $(-0.910)$ & $(-0.190)$ & & & $(-2.650)$ & $(0.430)$ \\
\hline M\&A Experience & -0.002 & & & -0.001 & $-0.012 * * *$ & & & -0.009 & $-0.008 * *$ & & & $-0.012 * *$ \\
\hline
\end{tabular}




\begin{tabular}{|c|c|c|c|c|c|c|c|c|c|c|c|c|}
\hline & $(-0.974)$ & & & $(-0.280)$ & $(-3.220)$ & & & $(-1.510)$ & $(-2.463)$ & & & $(-2.090)$ \\
\hline Target Firm Size & & & & $\begin{array}{c}0.001 \\
(0.510)\end{array}$ & & & & $\begin{array}{c}0.001 \\
(0.590)\end{array}$ & & & & $\begin{array}{c}0.000 \\
(0.220)\end{array}$ \\
\hline $\begin{array}{l}\text { Target Firm Industry- } \\
\text { Relative Size }\end{array}$ & & $\begin{array}{c}0.019 \\
(1.180)\end{array}$ & $\begin{array}{l}0.024 * \\
(1.740)\end{array}$ & & & $\begin{array}{c}0.002 \\
(0.060)\end{array}$ & $\begin{array}{c}0.019 \\
(0.610)\end{array}$ & & & $\begin{array}{c}-0.021 \\
(-0.670)\end{array}$ & $\begin{array}{c}-0.019 \\
(-0.690)\end{array}$ & \\
\hline Cons. & $\begin{array}{c}0.003 \\
(0.619)\end{array}$ & $\begin{array}{c}0.035 \\
(1.550)\end{array}$ & $\begin{array}{l}-0.005 \\
(-0.560)\end{array}$ & $\begin{array}{c}0.057 * * * \\
(3.350)\end{array}$ & $\begin{array}{c}0.001 \\
(0.089)\end{array}$ & $\begin{array}{l}-0.003 \\
(-0.100)\end{array}$ & $\begin{array}{c}-0.051 * * * \\
(-3.120)\end{array}$ & $\begin{array}{c}0.106 * * * \\
(4.600)\end{array}$ & $\begin{array}{c}-0.007 \\
(-0.577)\end{array}$ & $\begin{array}{c}0.002 \\
(0.060)\end{array}$ & $\begin{array}{c}0.000 \\
(-0.030)\end{array}$ & $\begin{array}{c}0.019 \\
(0.780)\end{array}$ \\
\hline $\begin{array}{l}\text { Firm specific control } \\
\text { variables }\end{array}$ & $\sqrt{ }$ & $\sqrt{ }$ & $\sqrt{ }$ & $\sqrt{ }$ & $\sqrt{ }$ & $\sqrt{ }$ & $\sqrt{ }$ & $\sqrt{ }$ & & $\sqrt{ }$ & $\sqrt{ }$ & $\sqrt{ }$ \\
\hline Industry/Year controls & $\sqrt{ }$ & $\sqrt{ }$ & $\sqrt{ }$ & $\sqrt{ }$ & $\sqrt{ }$ & $\sqrt{ }$ & $\sqrt{ }$ & $\sqrt{ }$ & & $\sqrt{ }$ & $\sqrt{ }$ & $\sqrt{ }$ \\
\hline Obs. & 3,243 & 536 & 656 & 1,265 & 3,063 & 536 & 656 & 1,265 & 3,063 & 536 & 656 & 1,265 \\
\hline $\operatorname{Adj} R^{2}(\%)$ & 1.40 & 7.73 & 4.50 & 7.85 & 3.91 & 4.09 & 3.39 & 7.37 & 2.32 & 2.77 & 2.77 & 5.36 \\
\hline
\end{tabular}

This table reports the cumulative abnormal returns (CAR) surrounding cross-border M\&A announcements. The sample comprises 3,821 M\&As undertaken by UK listed firms announced between $01 / 01 / 2000$ and 31/12/2010. The CARs are estimated for the windows $(-1,+1),(-10,+10)$, ($20,-2)$. Daily abnormal returns are measured based on the single factor market model estimated using a year of daily trading data prior to the announcement date. Panel A presents the average CAR, standard deviation (SD), number of observations, and the p-value for the differences of means between each type of M\&A deal announcement (i.e. domestic or cross-border) and deal size (i.e. small: below the median deal size; large: equal or above the median deal size). Panel B presents the regression estimates of the different deal- and investor-specific characteristics against the CARs. The variables employed in the regressions are defined as in Table 1. All accounting data are taken at year-end prior to the M\&A deal announcement. t-statistics based on cluster-adjusted robust standard errors (Petersen, 2009, hence providing robust interpretations (Cameron et al., 2008)) are reported in parentheses. ***, **, and * represent significance at $1 \%, 5 \%$, and $10 \%$, respectively. 